\title{
Last interglacial sea-level history from speleothems: a global standardized database
}

\author{
Oana A. Dumitru ${ }^{1}$, Victor J. Polyak ${ }^{2}$, Yemane Asmerom², and Bogdan P. Onac \\ ${ }^{1}$ Biology and Paleo Environment Department, Lamont-Doherty Earth Observatory, Columbia University, \\ Palisades, NY 10964, USA \\ ${ }^{2}$ Department of Earth and Planetary Sciences, University of New Mexico, Albuquerque, NM 87131, USA \\ ${ }^{3}$ School of Geosciences, University of South Florida, 4202 E. Fowler Ave., NES 107, Tampa, FL 33620, USA \\ Correspondence: Oana A. Dumitru (odumitru@ldeo.columbia.edu)
}

Received: 12 December 2020 - Discussion started: 17 December 2020

Revised: 5 April 2021 - Accepted: 9 April 2021 - Published: 18 May 2021

\begin{abstract}
Speleothems (secondary cave carbonate precipitates) are archives of valuable information for reconstructing past sea levels as they are generally protected from weathering and erosion by their location and can be dated with U-series methods. Two main categories of speleothems are recognized as sea-level indicators: phreatic overgrowth on speleothems (POSs) and submerged vadose speleothems (SVSs). POSs have the great advantage that they precipitate on preexisting supports (vadose speleothems or cave walls) at a brackish water level equivalent to sea level when air-filled chambers of coastal caves are flooded by rising sea. SVSs are also useful, but sea level is inferred indirectly as periods of growth provide constraints on maximum sea-level positions, whereas growth hiatuses, sometimes difficult to observe, may indicate times when cave passages are submerged by sea highstands; hence they record minimum sea-level elevations.

Here we describe a compilation that summarizes the current knowledge of the complete last interglacial (in its broadest sense from $\sim 140$ to $70 \mathrm{ka}$, also known as marine isotope stage (MIS) 5) sea level captured by speleothems. We used the framework of the World Atlas of Last Interglacial Shorelines (WALIS), a comprehensive sea-level database, to provide a standardized format in order to facilitate scientific research on MIS 5 sea level. The discussion is focused on MIS 5e, but records that capture MIS 5d, 5c, 5b, and 5a are also included. We present the data from 71 speleothems (36 sea-level index points and 37 limiting points) in coastal caves located in 10 different locations, and we include the spatial coverage, the samples used, and their accuracy as indicators of sea level, $\mathrm{U}$ and Th isotopes used to generate the chronologies, and their scientific relevance to understand past sea-level changes. Furthermore, the paper emphasizes the usefulness of these indicators not only to render information regarding the eustatic sea level, but also for their contribution to refine the glacial isostatic adjustment models and to constrain regional tectonic uplift rates. The standardized sea-level database presented here is the first of its kind derived from speleothems and contains all the information needed to assess paleo relative sea levels and the chronological constraints associated with them. The database is available open-access at https://doi.org/10.5281/zenodo.4313860 (Dumitru et al., 2020). We refer the readers to the official documentation of the WALIS database at https://walis-help.readthedocs.io/en/latest/ (last access: 20 January 2021), where the meaning of each field is explained in detail.
\end{abstract}




\section{Introduction}

Understanding sea-level changes during the last interglacial period (MIS 5e; in its strictest sense from 130 to $116 \mathrm{ka}$ ) is key to assess the behavior of ice sheets in a warmer world as MIS $5 \mathrm{e}$ is considered a potential analog for the future sealevel rise due to anthropogenic global warming since temperatures were on average $\sim 1.5^{\circ} \mathrm{C}$ higher than today (relative to the 1961-1990 CE period; Turney and Jones, 2010). Sea-level indicators formed during MIS 5e are often better preserved compared to those from earlier interglacial periods, and thus, relative sea level (RSL) during this time interval is especially informative (Capron et al., 2019). However, significant uncertainties regarding the precise timing, duration, and amplitude of MIS 5e sea level remain. The main limiting factor is finding a sea-level indicator that can robustly constrain both water depth and age. Fossil corals can be dated to relatively high precision but have meter-scale uncertainties in the reconstructed sea level (Hibbert et al., 2016; Chutcharavan and Dutton, 2021). Other indicators, such as erosional notches (Bini et al., 2014; Antonioli et al., 2015) or flank margin caves (Carew and Mylroie, 1995; Mylroie et al., 2020) pinpoint sea level, but lack tight age control. For this reason, there is a growing demand in exploring sea-level indicators that can simultaneously provide a robust chronology and have a clear indicative meaning.

Relevant sea-level markers such as flank margin caves (Mylroie et al., 2020), tidal notches (Bini et al., 2014), phreatic overgrowths on speleothems, and vadose submerged speleothems (Richards et al., 1994; Onac et al., 2012) are unique to coastal karst environments (Van Hengstum et al., 2015). Over the past decade, there has been a growing interest in cave deposits that allow for sea-level reconstructions, which include phreatic overgrowths on speleothems (POSs; indicative of the position of sea-level stillstands) and submerged vadose speleothems (SVSs; providing maximum elevations of sea-level position). A very large number of speleothem records have been reported and a comprehensive compilation by the Speleothem Isotope Synthesis and AnaLysis working group was used for multiple climate reconstructions and model evaluations (Atsawawaranunt et al., 2018; Comas-Bru et al., 2020). However, the majority of these studies are mainly directed towards paleoclimate reconstructions and only a handful focused on documenting sea-level changes as recorded by these deposits. The idea of using speleothems in reconstructing Quaternary sea-level changes dates back 5 decades (Benjamin, 1970; Spalding and Mathews, 1972; Ginés and Ginés, 1974). Relative to corals, an advantage of employing speleothems as sea-level markers is that the dense cave calcite is less susceptible to alteration. An additional benefit is that karst caves provide an excellent and sheltered environment in which these deposits are well preserved and protected against processes that disrupt or destroy other terrestrial archives.

\subsection{The relationship between POS/SVS deposition and sea-level changes}

\subsubsection{Phreatic overgrowths on speleothems}

POSs form on submerged cave walls and pre-existing vadose speleothems at and just below the water table (Ginés et al., 2012), when seawater mixes with meteoric water inside caves that are located in close proximity to the coastline (within $300 \mathrm{~m}$ ). The pre-existing vadose speleothems become partly submerged in the resulting brackish water (Fig. 1a). Previous petrographic investigations of these deposits suggested that the major control on carbonate precipitation is the ability of $\mathrm{CO}_{2}$ to degas across the water-air interface (Pomar et al., 1976; Csoma et al., 2006). These findings are supported by present-day observations that indicate the upper $40 \mathrm{~cm}$ of the water column is supersaturated with respect to calcium carbonate, allowing for POS to form (Boop et al., 2014). While meteoric-marine mixing zones are mostly referred to as sites of extensive dissolution, aragonite or calcite precipitation occurs when a high concentration gradient between $p \mathrm{CO}_{2}$ of the cave water and atmosphere exists. Therefore, faster degassing is expected to happen in caves with low $\mathrm{CO}_{2}$ partial pressure $\left(p \mathrm{CO}_{2}\right)$ in their atmosphere. Corrosion of carbonate minerals was noticed in some Majorcan caves, particularly when approaching the halocline; however, both calcite and aragonite are presently precipitating at the water table in the mixing zone, where the numerical model predicts dissolution (Csoma et al., 2006).

With very few exceptions, the morphology of the POS is clearly different from that of speleothems precipitated at the freshwater level in pools from non-coastal caves, e.g., shelfstones and subaqueous freshwater pool spar, on which the overgrowths are truncated in the upper part and mainly accrete under the water level. Furthermore, the carbonate deposition of these speleothems is not symmetric with respect to the water level and the tide range, which is a particularity of POS. The only instance when the shape of POS is asymmetric (i.e., form only under the water level) is when the preexisting vadose speleothem (i.e., stalagmite) was not long enough to capture the full range of the tide, which is responsible for their spherical or elliptical morphology. POS can take a variety of shapes and sizes (Fig. 1e, f), depending on the morphology of the vadose support, how long they were immersed in the cave's brackish water, and the tide amplitude. Only a few petrological and geochemical studies have been performed so far (Pomar et al., 1976; Ginés et al., 2005, 2012; Csoma et al., 2006). The mineralogical and crystallographical data indicate calcite as the dominant phase with fibrous, elongated, and isometric crystals, but radial-fibrous/acicular aragonitic fabric can exceed $70 \%$ in some samples (Ginés et al., 2012). A limited number of stable isotope analyses showed an isotopic evolution towards heavier composition through the MIS 5e and 5a possibly due to excessive marine water intrusion in the cave ponds (Vesica et al., 2000). 


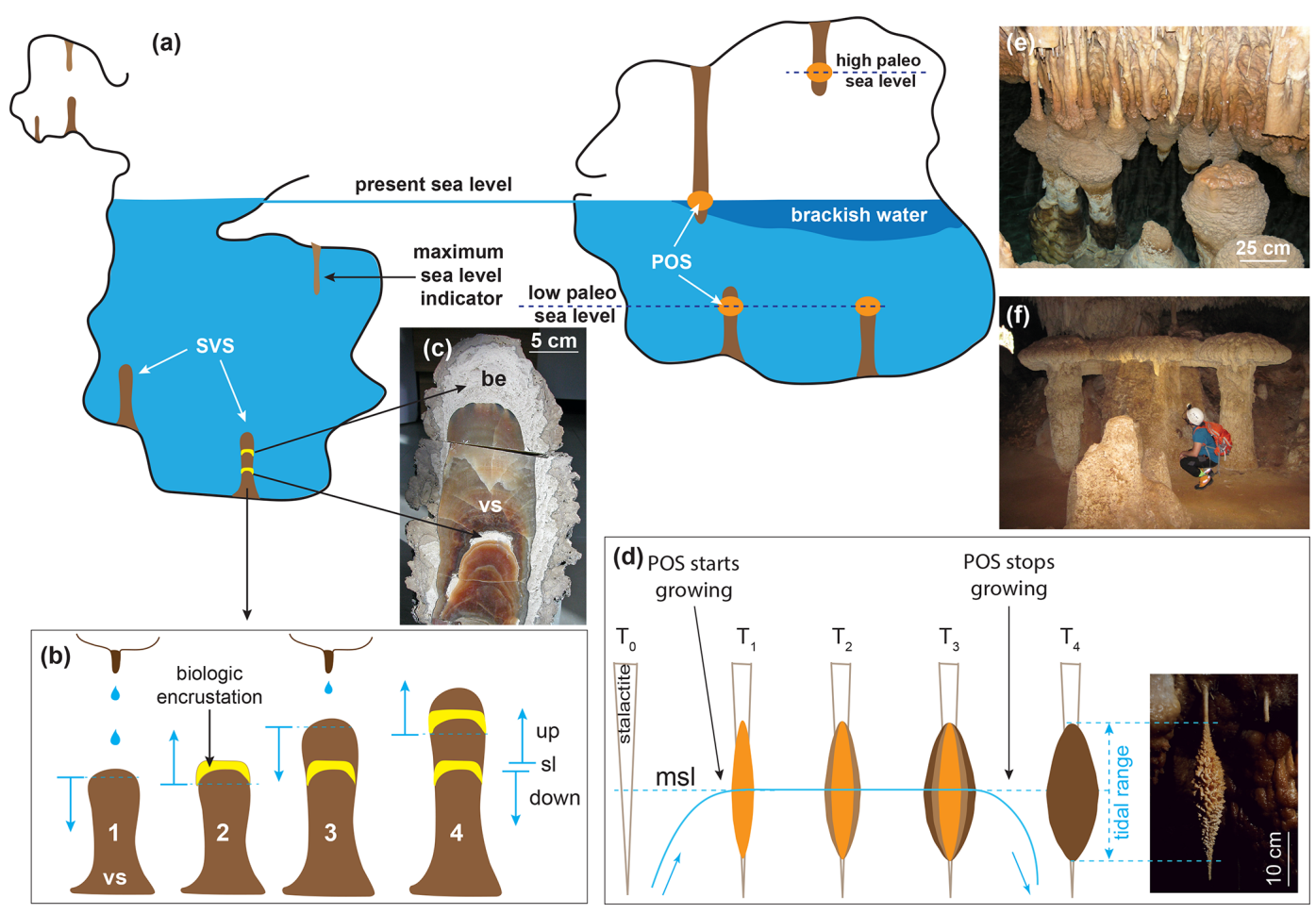

Figure 1. (a) Composite diagram showing how submerged vadose speleothems (on the left) and phreatic overgrowths on speleothems (on the right) in littoral caves act as sea-level indicators. (b) Conceptual model showing that (b1) growth of SVSs indicates times when sea level was lower than their elevation; (b2) Hiatus - period of SVS submergence suggesting sea level higher than the SVS elevation; (b3) SVSs resume their deposition when sea level fell below its elevation. (c) SVS (be: biogenic encrustation; vs: vadose speleothem) from Argentarola Cave, Italy (photo courtesy Fabrizio Antonioli). (d) Conceptual models showing how POSs form; as long as sea level remains at the same elevation (T1-T3) POSs will precipitate at sea level and within tidal range and will continue to grow until the sea level drops below the speleothem (T4). (e) Late Holocene POS in Cala Varques Cave, Majorca. (f) Mushroom-shaped POS in Santa Catalina Cave, Cuba (photo courtesy Bogdan P. Onac).

More in-depth studies have been undertaken to investigate the POS precipitation conditions and the relationships between surface conditions (temperature, barometric pressure, precipitation, tidal level of the sea) and the microenvironment of coastal caves (temperature, $p \mathrm{CO}_{2}$, and water level; Boop et al., 2014). The distinction between POS and shelfstones (flat deposits attached to cave walls or on partly immersed speleothems that grow inwards from the edge of the pool/speleothem) is clearly described in Onac et al. (2012).

The hydraulic gradient between caves hosting POS and the sea is insignificant, since the caves are proximal to the coastline, and thus, the brackish water table in these caves is, and was in the past, coincident with sea level. As long as sea level remains at the same elevation, carbonate precipitation occurs within the tidal range at the air-water interface (Vesica et al., 2000; Fornós et al., 2002; Dorale et al., 2010; Polyak et al., 2018). Therefore, the presence of POS horizons at different elevations precisely marks the positions of paleo-water tables and consequently their associated sea-level position. Given the precipitation mechanism (Fig. 1d), POSs arguably provide the most precise and less ambiguous indicator of the absolute elevation of sea-level position. POSs are meaning- ful sea-level index points because they provide spatial geographic positioning, accurate elevation, and absolute ages. This type of cave deposit has only been identified in a few places worldwide: Majorca (Ginés and Ginés, 1974; Vesica et al., 2000; Tuccimei et al., 2007; Dorale et al., 2010; Polyak et al., 2018; Dumitru et al., 2019); Sardinia (Tuccimei et al., 2012); Nansei islands, Japan (Pacific Ocean; UrushibaraYoshino, 2003; Minami Daito Island; Miklavič et al., 2018); Christmas Island, Australia (Indian Ocean; Grimes, 2001); and Mexico (Jenson, 2018). Similar deposits have been recently described and dated from Santa Catalina Cave in Cuba (De Waele et al., 2017, 2018). While of different morphologies, such as mushroom caps and bench-like encrustations similar to cave shelfstones (called balconies), they appear to be POSs (Fig. 1f). Earlier investigations of these speleothems suggested that their formation is highly dependent on microbial activity and water level fluctuation (Bontognali et al., 2016). 


\subsubsection{Submerged vadose speleothems}

Speleothems such as stalactites and stalagmites form in airfilled passages (Fig. 1a); thus periods of their growth indicate times when sea level was lower; hence they are sea-level terrestrial limiting points. For vadose speleothems that are subject to sea-level submergence, hiatuses (i.e., no carbonate deposition) can be correlated with periods when sea level rose and inundated the cave, causing speleothem growth to cease. Important to note is that a prolonged pause in speleothem growth is not always caused by sea-level rise; changes in hydrology and hydrochemistry above the cave, for example, undersaturation of drip water or cessation of dripping (drought or blockage of drainage path), can also lead to interruption of speleothem deposition (Onac et al., 2012). When growth cessation is sea-level related, particular mineralogical and/or biological features can be visible using petrography. Some of these include (i) corroded layers when dissolution happens at the halocline, (ii) biogenic encrustations (Fig. 1b, c), (iii) traces of marine borings, and (iv) deposition of various trace elements or minerals (halite, gypsum, etc.). Details regarding ways of deciphering different types of growth hiatuses are presented by Onac et al. (2012) and van Hengstum et al. (2015). Dating the carbonate layer immediately above each of these hiatuses provides a minimum estimate of when the cave became air-filled, again constraining the minimum age for the sea-level fall. The carbonate layer below a hiatus indicates the maximum age, assuming no post-depositional alteration of the exposed surfaces, for when this location in the cave was air-filled and the sea level was clearly below the speleothem elevation. It is worth noting that the earliest layers deposited above the hiatuses are protected by further carbonate precipitation, whereas those below the hiatuses are susceptible to diagenetic alteration or even dissolution. Thus, such carbonate accumulations provide precise age constraint on the initiation of growth but may not tell exactly when sea level dropped.

SVSs stop growing when sea level is above their elevation and restart their deposition when sea level falls below it (Fig. 1b); thus, they record past sea-level fluctuations indicating when the cave was air-filled or invaded by seawater (Richards et al., 1994; Moseley et al., 2013). Once the sea level falls again, if conditions are suitable, the speleothem may resume its deposition. Hence, the vadose speleothems can only provide the minimum and maximum age when a particular part of the cave became flooded or air-filled, not precisely when and where the water level was actually located throughout the bulk of the rise-fall cycle (Richards et al., 1994; Surić et al., 2009). Therefore, the growth of vadose speleothems is a limiting point, and thus, its relationship with the sea-level position must be interpreted correspondingly. The submerged speleothem indicators can be refined by dating alternating continental and marine biogenic overgrowths (serpulid colonies) if they exist and are well preserved (Antonioli et al., 2004; Dutton et al., 2009), but since none of them captured the MIS 5 sea-level stand, they are not discussed in this paper. The age of growth initiation and cessation is dependent on sample position and growth rate. A highly resolved U-Th chronology defines the degree of continuous growth, and a high-quality petrographic examination of the sample would support that. These ages can be used to calculate the growth rate, allowing a better definition of the onset and cessation of deposition for either POS or SVS samples. This information bears significance since one can use the growth rate to project the onset of a hiatus, which in coastal caves provides evidence for when sea level emerged above that particular speleothem elevation. To provide robust chronologies, we refer the readers to the workflow to treat records with hiatuses developed by Comas-Bru et al. (2020).

\subsection{Existing MIS 5e sea-level databases and context of our work}

Extensive reviews of MIS 5e sea-level indicators (coral reef and marine terraces, shore platforms, beach deposits and ridges, tidal notches, and sea caves) at global scale have been compiled by Kopp et al. (2009), Dutton and Lambeck (2012), Pedoja et al. (2014), and Hibbert et al. (2016). A step forward was taken by Rovere et al. (2016a), who set the basis for a standardized approach to MIS 5e paleo sea-level reconstructions and interpreted the indicators in terms of the entire geological or sedimentary facies, rather than considering each of them separately. Standardized sea-level databases allow for regional to global comparisons of records from disparate locations. In turn, this provides a means to disentangle spatial patterns and rates of sea-level change at different timescales. These curated sets of data will ultimately enhance our understanding of the mechanisms driving sea-level fluctuations, thus improving both physical models and statistical reconstructions (Khan et al., 2019).

Speleothems have received little or no attention in prior compilations. A thorough review of the results obtained from the study of Mediterranean submerged speleothems since 1978 and their use to reconstruct past sea-level variations has been recently provided by Antonioli et al. (2021). Still, a dedicated cave deposit database is not currently available to the sea-level community. In this context, the present dataset paper aims to compile existing results on cave-deposit-derived sea level during the last interglacial period and make them more accessible to the paleoclimatology and oceanography community, with the ultimate goal of facilitating research on MIS 5 sea level. This work gathers data from previously published studies, each of which describes the samples analyzed, the isotopic ratios and concentrations used to generate the chronology, and the scientific relevance for interpreting past sea-level changes. Section 2 presents the data, including the criteria for the inclusion of each record such as spatial coverage, the elevation measurements and their uncertainties, and the U-Th methods for their absolute chronology. Section 3 discusses the interpretation of these records and highlights 
the valuable information they provide for eustatic sea level and the crucial inputs in assessing glacial isostatic adjustment (GIA) models and regional tectonic activity.

\section{Data description}

The data presented here are part of the World Atlas of Last Interglacial Shorelines (WALIS, https://warmcoasts.eu/ world-atlas.html, last access: 12 April 2021), a sea-level database interface developed under the framework of the European Research Council Starting Grant "WARMCOASTS" (ERC-StG-802414), in collaboration with PALSEA (PALeo constraints on SEA level; a PAGES-INQUA working group). WALIS provides a new standardized database and aims to be the most comprehensive compilation of globally distributed (new and old) data on MIS 5 sea-level indicators. The interface allows a large range of data and metadata on relative sea-level indicators and associated ages to be inserted into a mySQL database. An export tool allows one to download the data inserted by the logged user as a multi-sheet Microsoft Excel .xls file. This archive is available open-access as Dumitru et al. (2020; https://doi.org/10.5281/zenodo.4313860). We refer the readers to the official documentation of the WALIS database at https://walis-help.readthedocs.io/en/ latest/ (last access: 12 April 2021), where the meaning of each field is explained in detail. These files will be available in WALIS v1.0, which will provide a user-friendly interface for quick visualization, extraction, and downloading of the data. We summarize below the major features of the records which comprise the database in metadata fields that enable easy reuse of the time-series data. In order to ensure high-quality data intended for scientific reuse, only results published in peer-reviewed literature were considered.

\subsection{Criteria for record inclusion}

The use of speleothems as sea-level indicators has been reported from several places around the world; however, in this data paper we only present the results that capture sea level during the complete last interglacial (MIS 5; 140-70 ka). The discussion is mostly centered around MIS 5e, but also includes results on the sea-level position during MIS 5d, 5c, 5b, and 5a. A number of POSs older or younger than MIS 5 have been published from caves in Majorca (Vesica et al., 2000; Dumitru et al., 2019, 2021), Japan (Miklavič et al., 2018), and Mexico (Jenson, 2018), but they are not included in this paper. Similarly, SVSs (some of which are at much lower elevations than the ones presented here) have been identified in several submerged caves in the Bahamas and Mediterranean, but their ages are far too old (Richards, 1995; Smart et al., 2008) or young (Spalding and Mathews, 1972; Beck et al., 2001; Hoffmann et al., 2010; Arienzo et al., 2015, 2017; Antonioli et al., 2021) to be directly relevant for MIS 5 sea-level reconstruction.
This database includes a total of 71 speleothems (36 sealevel index points and 37 limiting points) of variable quality. All the POS records have precisely measured elevations, a narrow indicative range, and decimetric RSL uncertainties; hence they are excellent sea-level indicators. A guide for SVS records' evaluation as terrestrial limiting points can be found in WALIS' official documentation (https://walis-help. readthedocs.io/en/latest/RSL_data.html; last access: 8 May 2021). Worth noting is that the ages that are near but outside the MIS 5 range are not included in the discussion of this paper, but, for completeness, they are entered in the database.

\subsection{Spatial coverage}

Phreatic carbonate overgrowths on speleothems dating to MIS 5 are found in caves along the coasts of Majorca (Vesica et al., 2000; Fornós et al., 2002; Dorale et al., 2010; Tuccimei et al., 2012; Polyak et al., 2018), the northern coast of Cuba (De Waele et al., 2017, 2018), and to a lesser extent in Sardinia (Tuccimei et al., 2007). Submerged vadose speleothems were investigated from Bermuda (Harmon et al., 1978; 1981; Wainer et al 2017), the Bahamas (Gascoyne et al., 1979; Gascoyne, 1984; Li et al., 1989; Lundberg and Ford, 1994; Richards et al., 1994; Smart et al., 1998), the Yucatán Peninsula (Moseley et al., 2013), Croatia (Surić et al., 2009; Surić and Juračić, 2010), and Italy (Tuccimei et al., 2007; Bini et al., 2020). Except for the SVSs from the Yucatán Peninsula reported by Moseley et al. (2013) and from Bermuda (Wainer et al., 2017), studies do not report the exact cave location from where samples were collected. Hence, the latitude and longitude for these indicators were determined using Google Earth to match locations from publication maps and noted accordingly. The geographical distribution shows all sites are located in the Northern Hemisphere within 20 and $45^{\circ}$ latitude N (Fig. 2).

\subsection{Elevation measurements and their uncertainties}

The sample elevation is the vertical distance between the indicator and a vertical datum (i.e., a "zero" reference frame, representing modern mean sea level) and is a fundamental property measured in the field. All samples have been reported relative to present mean sea level. Several instruments with different uncertainties have been used to measure the elevation of the speleothems: barometric altimeter $( \pm 0.1 \mathrm{~m}$; Moseley et al., 2013), metered tape or rod ( $\pm 0.5 \mathrm{~m}$; Harmon et al., 1978), and/or inclinometer $( \pm 0.05 \mathrm{~m}$; Dorale et al., 2010). The uncertainties of Majorcan POS elevation, even though some of the samples are collected from the same cave, vary depending on the instrument used (e.g., $\pm 0.1 \mathrm{~m}$ in Tuccimei et al., 2007, and Polyak et al., 2018; $\pm 0.05 \mathrm{~m}$ in Dorale et al., 2010). The POS belt from Cuba occurs within $0.4 \mathrm{~m}$, more or less corresponding to the average tidal range measured in the city of Matanzas $(<25 \mathrm{~km} \mathrm{NE}$ from the cave site). In some cases, information regarding elevation mea- 
Table 1. Sites included in data product. Location and name of the caves, type of speleothems, and the corresponding references.

\begin{tabular}{|c|c|c|c|}
\hline Location & Cave name & $\begin{array}{l}\text { Type of } \\
\text { speleothem }\end{array}$ & Reference \\
\hline \multirow[t]{2}{*}{ Majorca, Spain } & Cova de Cala Varques A & \multirow[t]{2}{*}{ POS } & Dorale et al. (2010); Polyak et al. (2018) \\
\hline & $\begin{array}{l}\text { Cova de Cala Varques B } \\
\text { Cova del Dimoni } \\
\text { Cova de Cala Falcó } \\
\text { Cova des Pas de Vallgornera } \\
\text { Cova Genovesa } \\
\text { Cova de s'Ònix } \\
\text { Coves del Pirata } \\
\text { Cova des Serral } \\
\text { Coves del Drac } \\
\text { Cova de sa Tortuga }\end{array}$ & & Polyak et al. (2018) \\
\hline Sardinia, Italy & Grotta di Nettuno & POS, SVS & Tuccimei et al. (2007) \\
\hline Italy & Infreschi Cave & SVS & Bini et al. (2020) \\
\hline Cuba & Santa Catalina Cave & POS & De Waele et al. $(2017,2018)$ \\
\hline \multirow[t]{2}{*}{ Bermuda } & $\begin{array}{l}\text { Government Quarry Cave } \\
\text { Bierman Quarry Cave } \\
\text { Crystal Cave }\end{array}$ & \multirow[t]{2}{*}{ SVS } & Harmon et al. $(1978,1981)$ \\
\hline & Wilkinson Quarry Cave & & Wainer et al. (2017) \\
\hline Yucatán Peninsula & Caves in Quintana Roo & SVS & Moseley et al. (2013) \\
\hline Krk Island, Croatia & U Vode Pit & SVS & Surić et al. (2009) \\
\hline Lošinj Island, Croatia & Medvjeđa spilja Cave & SVS & Surić and Juračić (2010) \\
\hline \multirow[t]{3}{*}{ Andros Island, Bahamas } & Blue Hole in South Bight & \multirow[t]{3}{*}{ SVS } & Gascoyne et al. (1979) \\
\hline & Stargate Blue Hole & & Richards et al. (1994); Smart et al. (1998) \\
\hline & Conch Sound Blue Holes & & Gascoyne (1984) \\
\hline \multirow[t]{2}{*}{ Grand Bahama, Bahamas } & Lucayan Caverns & SVS & $\begin{array}{l}\text { Lundberg and Ford (1994) } \\
\text { Richards et al. (1994) }\end{array}$ \\
\hline & Sagittarius Cave & SVS & Richards et al. (1994) \\
\hline
\end{tabular}

surements and their uncertainties is not reported because the papers are not strictly sea-level studies but indirectly provide sea-level information, or because the uncertainties related to local tectonics are much larger than the measurement uncertainty (Surić et al., 2009). Samples reported by Gascoyne (1984) are missing information on their elevation; hence we only report their U-series ages in the database, and they are not considered terrestrial limiting points. However, we include here the existing elevations of these samples found in the McMaster University Speleothem Collection, 2008 (courtesy: Derek C. Ford): samples 81048, 81049, 81050 , and 81052 from $\sim 80 \mathrm{~m}$ below sea level; 81054 and 81055 from $\sim 3$ m a.p.s.l.; 76017 from shallower depth; and 78026 and 78027 from between 0 and $9 \mathrm{~m}$ below sea level.

\subsection{Samples}

In the WALIS database, each sample is assigned a sample ID that is composed of the first two letters of the main author's last name, followed by the year of publication and a number code given to each speleothem individually (see Table 2 as an example). The analysis ID complements the sample ID by including a distinct number for when two or more ages are reported for the same speleothem. Finally, the reported ID is the published sample identifier or laboratory ID offered by the authors in the original paper. Since samples once collected may end up having several IDs (collection, dating lab, etc.), it is recommended that whenever included in a database, authors should always use the ID associated with its first description and when the lab ID is different, this should also be added. We note that for samples that have a 


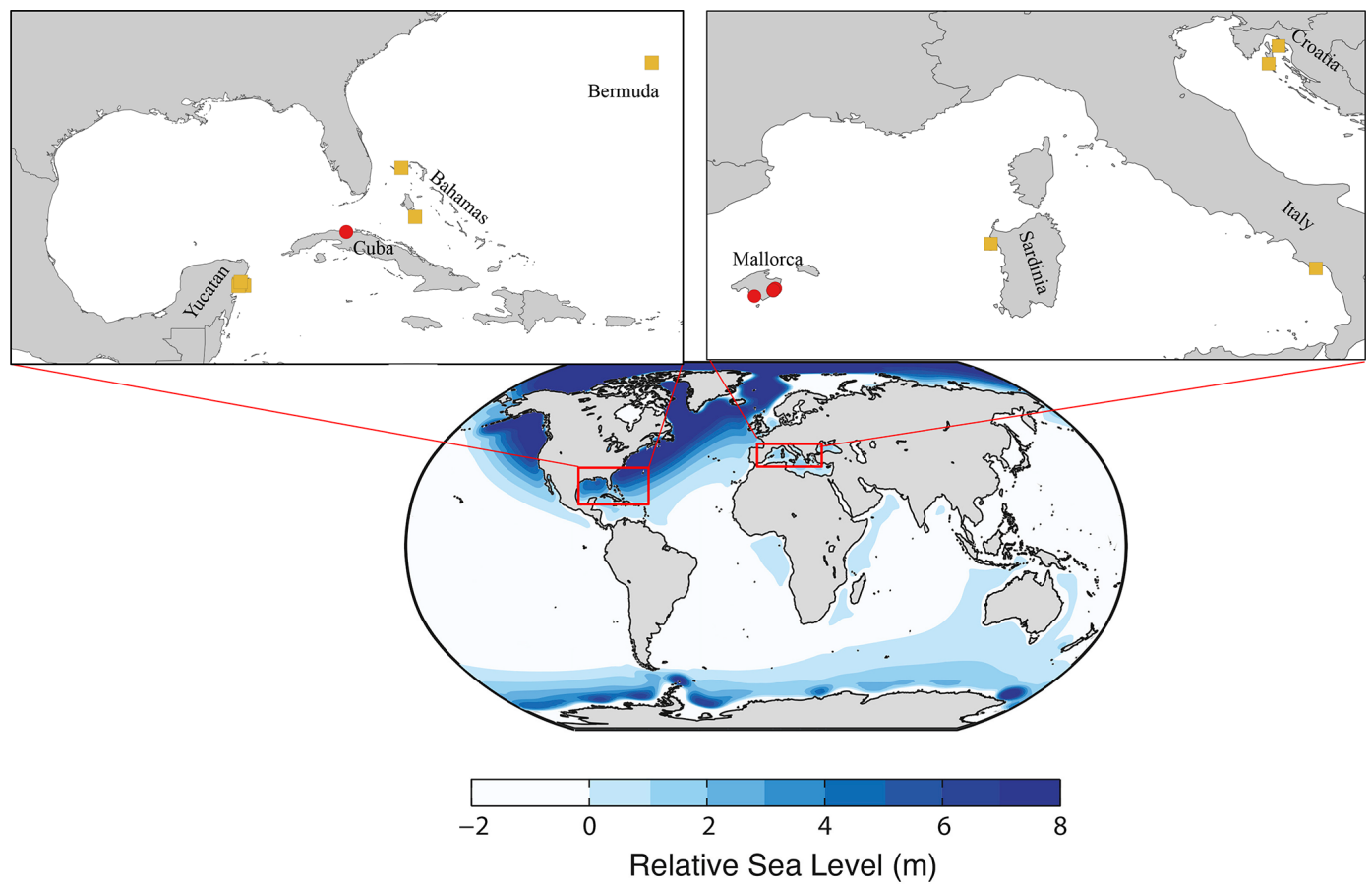

Figure 2. (a) Global map showing the predicted RSL near the end (119ka) of the modeled MIS 5e (see Fig. 2 of paper: https://doi.org/ 10.1016/j.quascirev.2017.06.013; Dendy et al., 2017) to highlight the potential of the samples' sites to record the behavior of the forebulge during ice-sheet loading and unloading. Sites where POS and SVS were documented and sampled are indicated by red circles and yellow squares, respectively.

Table 2. Example to show how samples are coded in the WALIS database.

\begin{tabular}{lll}
\hline Sample ID & Analysis ID & Reported ID \\
\hline DO10-001 & DO10-001-001 & CCVA-1 \\
DO10-002 & DO10-002-001 & CCVA-2 \\
DO10-003 & DO10-003-001 & CDD-1 \\
DO10-004 & DO10-004-001 & CDD-2 \\
DO10-005 & DO10-005-001 & CCVB \\
DO10-006 & DO10-006-001 & CCF-1 \\
DO10-007 & DO10-007-001 & CCF-2 \\
DO10-008 & DO10-008-001 & CPV-1 \\
DO10-009 & DO10-009-001 & CPV-2 \\
DO10-010 & DO10-010-001 & CPV-B8 \\
DO10-011 & DO10-011-001 & CPV-B6 \\
DO10-012 & DO10-012-001 & CPV-B9 \\
\hline
\end{tabular}

different laboratory ID than the sample identifier (i.e., Moseley et al., 2013) both are included in our reported ID.

A variety of different speleothems are reported to have recorded past sea levels. Stalagmites grow from the floor upward in caves, stalactites (dripstones) hang from the ceilings, and flowstones are sheetlike deposits that form on walls and floors. The POSs analyzed by Dorale et al. (2010) and Polyak et al. (2018) have a different size, shape, and morphology, depending on the vadose support and on the extent of their immersion in the brackish pool (Ginés et al., 2012). They are generally small enough to collect in situ, and larger POSs can be cored in place. The Cuban POSs investigated by De Waele et al. $(2017,2018)$ in Santa Catalina Cave are rare composite mushroom-shaped speleothems with caps reaching diameters $>1 \mathrm{~m}$ and balconies present along the walls. In this case, the authors analyzed samples from mushroom stalk or cap, balcony, and other associated speleothems. Most of the SVSs investigated as sea-level indicators are stalagmites, but results from flowstones and stalactites have been reported as well.

The caves have unique scientific, recreational, and scenic value; hence, speleothem sampling strategies must be selective and reconcile cave conservation with the scientific goal (Baeza et al., 2018). For this reason, we emphasize that the utmost effort should be made to minimize the future impacts of sampling by following the conservation and preservation guidelines. We strongly encourage more sustainable sampling strategies and, if sufficient material and appropriate documentation has been archived by the original authors, making them available for future researchers is desirable. Similarly, we recommend preferentially sampling already broken/damaged speleothems whenever the original location can be established, as suggested by Frappier (2008). Another sustainable sampling strategy is coring of speleothems rather than collecting the entire specimen and patching the drill holes (Spötl and Mattey, 2012). 


\subsection{Sample mineralogy}

The geochemical setting and sample mineralogy may dictate the susceptibility to alteration. For example, samples that show conversion of aragonite to calcite or calcite recrystallization could have been subjected to uranium loss, which is an important factor that impacts U-Th ages (Lachniet et al., 2012; Bajo et al., 2016). To allow recognition of diagenetic fabrics, XRD screening is desirable for dating purposes (aragonite is preferred vs. calcite). In order to make the best selection of samples, we encourage the use of petrographic investigation as well. Thin sections can help to best identify the speleothem layers just below and above the hiatus for dating purposes, and also, they reveal the internal structure, and so areas affected by recrystallization can be avoided while sampling. However, only some of the studies compiled here report the mineral assemblage of the samples by X-ray diffraction (Surić et al., 2009; Surić and Juračić, 2010; De Waele et al., 2017, 2018). De Waele et al. (2018), for example, complemented the screening method with petrographic investigations (thin sections) and imaging using scanning electron microscopy. We do not exclude the possibility that screening was performed in the other publications, but it has not been reported. For future studies, we strongly recommend including information on mineral assemblage, as well as diagenetic and crystalline descriptions.

\subsection{U-series methods}

Accurate geochronology is essential to these studies. Dutton et al. (2017) provide a template of what information should be reported for U-series data for geochronology and timescale assessment in the earth sciences. As was found for coral-based sea-level work, the speleothem U-series results reported often contain insufficient information to completely assess the data collected. This ultimately limits the value of the data since often it is not possible to assess or recalculate a date using the information provided. While it may not be practical to recalculate dates from older data, what is more important is to have data and methods so that decisions can be made to request or recollect samples of interest. We include in the database the U-series method used (alpha counting, thermal ionization mass-spectrometry (TIMS), multi-collector inductively coupled plasma mass spectrometry (MC-ICP MS)), the decay constants used, and the measured isotopic ratios and concentrations of the sample, all of which are required to recalculate U-Th ages and to assess their robustness. Generally, analyses of well-characterized internationally recognized standards or certified reference materials are used to demonstrate the reliability of results. Advances in technologies since the mid-1980s have notably increased the analytical precision and reduced age uncertainties, thereby allowing for dating of smaller sample sizes, which permits better sampling along single growth layers (thicker samples will integrate material of different ages).
The development of TIMS and then MC-ICP MS in measuring $\mathrm{U}$-series isotopes constituted a major step forward from the alpha spectrometric method (Hoffmann et al., 2007). The majority of the records compiled here were dated using MCICP MS, and only a few used or reported alpha spectrometry (Harmon et al., 1978, 1981; Gascoyne et al., 1979, Gascoyne, 1984; Smart et al., 1998; Vesica et al., 2000; Tuccimei et al., 2007) or TIMS results (Lundberg and Ford, 1994; Richards et al., 1994; Tuccimei et al., 2007; Dorale et al., 2010).

When provided by authors, the database also includes the initial ${ }^{230} \mathrm{Th} /{ }^{232} \mathrm{Th}$ ratios and the decay constants. The correction for the initial non-radiogenic sources (i.e., hydrogenous, colloidal, and carbonate or other detrital components; Richards et al., 2012) of ${ }^{230} \mathrm{Th}$ incorporated at the time of speleothem deposition is extremely important for age calculation and is sensitive for samples that contain very little uranium or an abundance of detrital thorium. The ${ }^{230} \mathrm{Th} /{ }^{232} \mathrm{Th}$ activity ratio of 0.825 with an arbitrarily assigned uncertainty of $50 \%$ found in the mean bulk Earth or upper continental crustal has been commonly assumed for initial ${ }^{230} \mathrm{Th}$ corrections. However, several studies have shown that this value may not cover all situations. Therefore, laboratories apply different corrections for the non-radiogenic detrital ${ }^{230} \mathrm{Th}$ fraction through either direct measurement of sediments associated with speleothems (Hoffmann et al., 2018) or computed isochron methods and stratigraphical constraints (Hellstrom, 2006; Richards et al., 2012). Most POSs included in this database fulfill the criterion suggested by Hellstrom (2006) that samples with ratios of ${ }^{230} \mathrm{Th} /{ }^{232} \mathrm{Th}$ higher than 300 are considered clean, with very few samples having lower ratio values (Tuccimei et al., 2007). However, the use of this threshold value is arbitrary and depends on the ratio used for initial Th. We emphasize that this database includes the ages as they are reported in the original publications, and therefore, it contains two columns: reported ages and corrected ages. The latter one represents the ages to which the original authors applied a correction for detrital Th based on the a priori estimate of initial Th. We did not apply any further corrections when compiling this database, and we also did not recalculate the ages. All data contain the minimum required information (as recommended in the Supplement of Comas-Bru et al., 2020) to calculate uncorrected ages; however, not all of them provide the initial ${ }^{230} \mathrm{Th} /{ }^{232} \mathrm{Th}$ activity ratio to allow the calculation of detritus-corrected ages. The decay constants for ${ }^{234} \mathrm{U}$ and ${ }^{230} \mathrm{Th}$ used to calculate the UTh ages have been updated and improved over time (Jaffey et al., 1971; Edwards et al., 1987; Cheng et al., 2000, 2013). Most recent papers used the ${ }^{234} \mathrm{U}$ and ${ }^{230} \mathrm{Th}$ decay constants of Cheng et al. (2000, 2013), but in some papers, especially in the older ones, these values are not provided. It is not likely that published U-Th dates will be corrected and reported, but rather that assessment of materials and their U-Th dates might be used to make decisions on the need to obtain those samples through request or recollect samples from the same outcrop or site. Identifying and defining continuous growth 


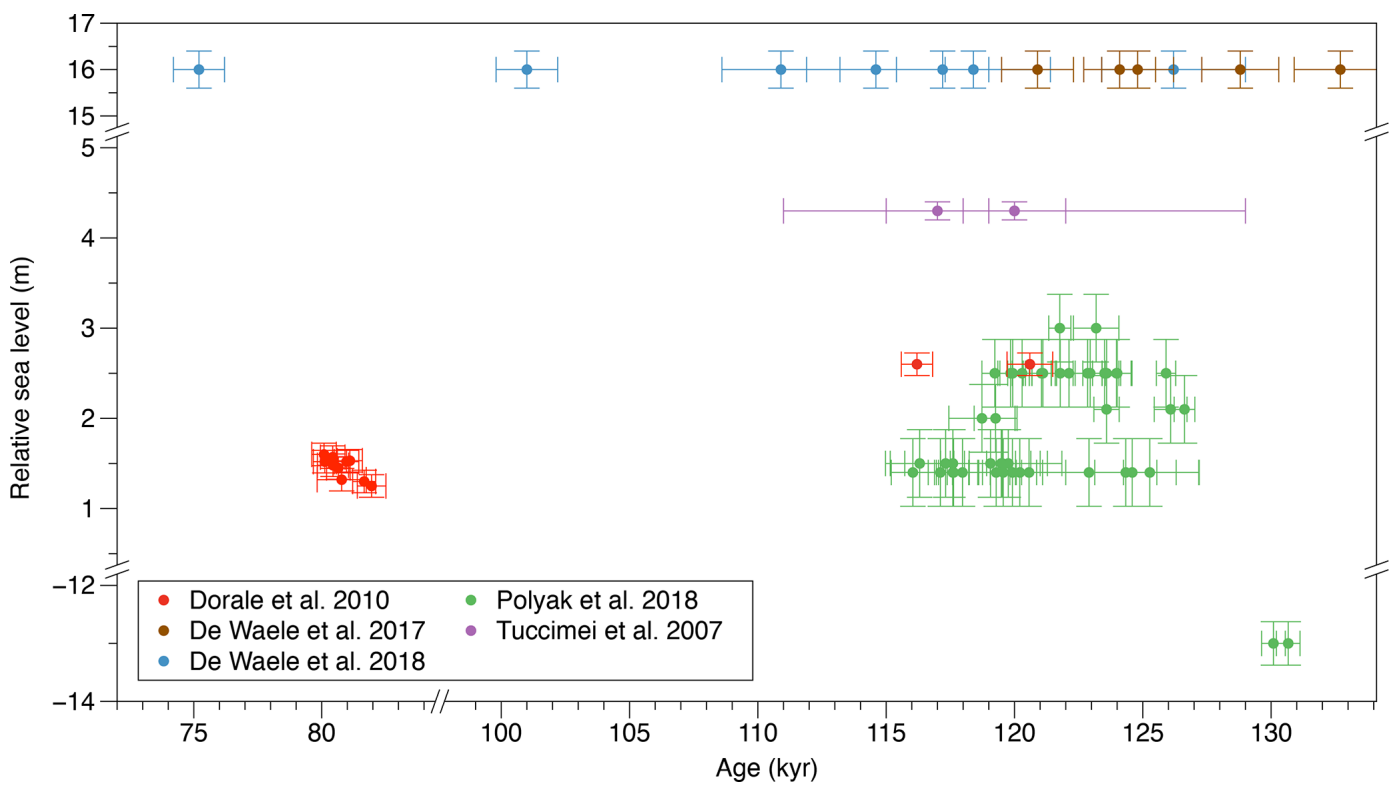

Figure 3. Paleo RSL position recorded by POS. Except for Tuccimei et al. (2007), all U-Th ages are corrected for detrital Th as per the original publications. No other corrections such as tectonic movement or GIA have been applied.

of vadose speleothems could be helpful to refine minimum or maximum sea-level elevations. However, continuous growth is strongly dependent on the reliability and resolution of the U-series chronology.

The datum for modern reference state of ages reported is either BP (or $1950 \mathrm{CE}$ ) or it is not mentioned, in which case the ages are assumed to be calculated with respect to date of analysis. This is usually not considered significant because the errors on MIS 5e ages are generally $>500$ years. However, with the improvements made using MC-ICP MS (Cheng et al., 2013), ages on high-quality samples (i.e., aragonite mineralogy, high $\mathrm{U}$ content, insignificant ${ }^{230} \mathrm{Th}$ correction) of the last interglacial are now possible to uncertainties of \pm 100 years $(2 \sigma)$, making how the age is reported more important (i.e., BP). Another reference commonly used now is yr b2k (years before $2000 \mathrm{CE}$ ). Except for Gascoyne (1984) and Gascoyne et al. (1979), where uncertainties are reported as $1 \sigma$, and Harmon et al. $(1978,1981)$, who reported standard error, or errors were not mentioned, all ages are reported with $2 \sigma$ absolute uncertainties. We refer the reader to the guide on the evaluation of the ages' quality, which can be found in WALIS' official documentation at https://walis-help.readthedocs.io/en/latest/RSL_data.html (last access: 8 May 2021). We strongly recommend the use of the term "uncertainty" which is more appropriate in this context than "error", as suggested by Dutton et al. (2017).

\section{Discussions}

The elevation of a sea-level indicator is not always coincident with the position of relative sea level at the time of its forma- tion, but rather is correlated to it by a quantifiable relationship. This is defined by the indicative meaning, a concept that needs to be considered when calculating the elevation of paleo RSL (Hopley, 1986; Shennan, 2015; Hibbert et al., 2016; Rovere et al., 2016a). To define the position of past sea level over space and time, the sea-level indicators need to provide information on the geographic positioning, elevation with respect to a contemporary tidal datum, age of formation, and indicative meaning (Shennan, 2015; Khan et al., 2019). Most records of MIS 5 sea level have come from coral reefs, but the interpretation is hampered by the challenges of finding pristine and well-preserved corals and the uncertainties related to the water depths above the corals. The past sea-level position in space and time indicated by speleothems depends on their type: (i) POSs have the ability to define the discrete position (Fig. 3), whereas (ii) SVSs provide only an upper bound (Fig. 4).

\subsection{POS define reliable positions of RSL}

POS precipitation was tentatively associated with past sealevel stands almost 5 decades ago (Ginés and Ginés, 1974), but due to advancements in the U-Th dating, only recently have studies demonstrated their suitability as meaningful sealevel index points (Vesica et al., 2000; Dorale et al., 2010; Tuccimei et al., 2012; Polyak et al., 2018; Dumitru et al., 2019, 2021). The most important benefit of using POSs as sea-level indicators is their unambiguous relationship to sea level. For example, the indicative range accounts for the vertical extent over which an entire POS forms, and the reference water level corresponds to their thickest part, which is the midpoint of the indicative range and the mean sea level. 


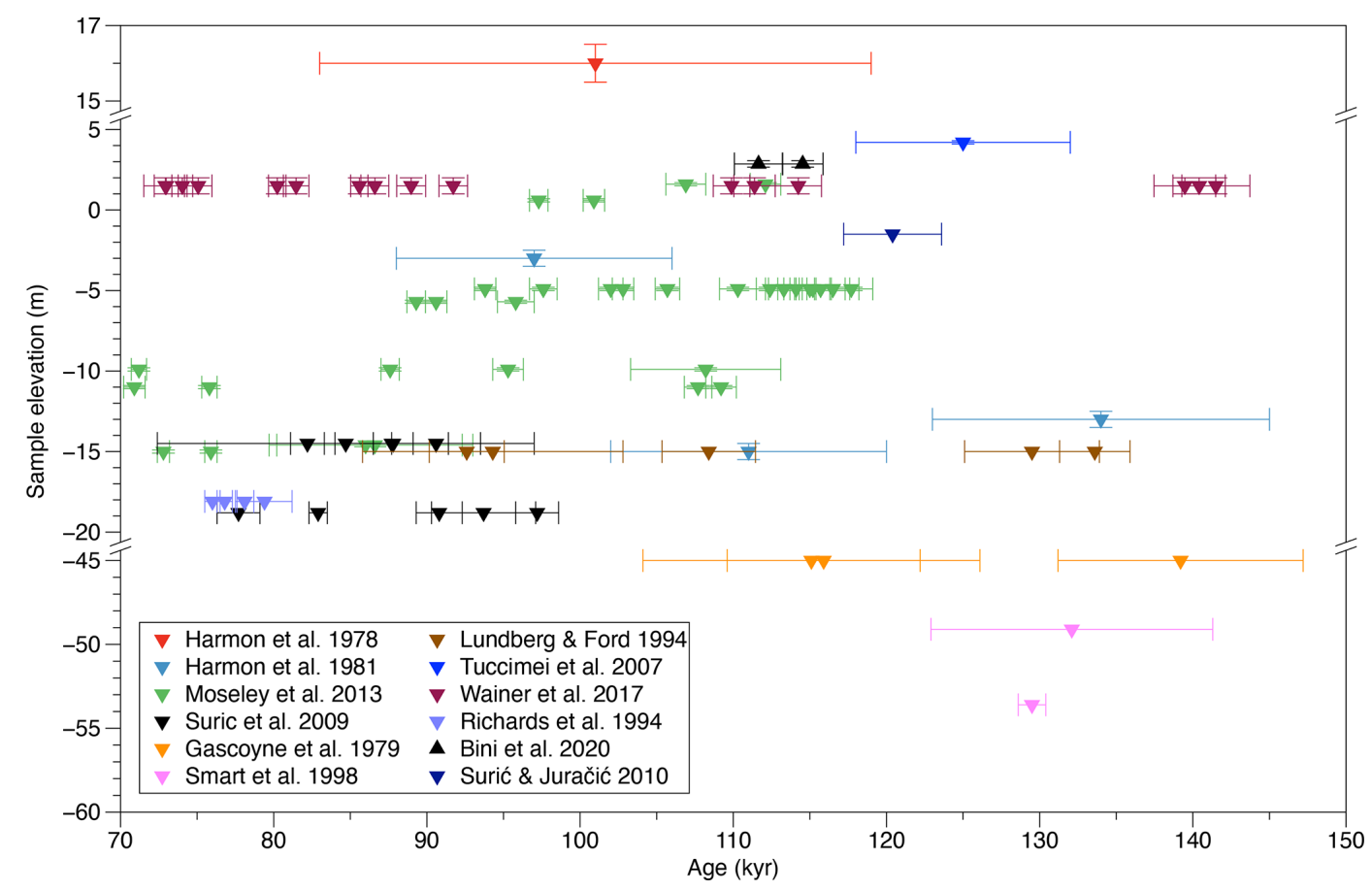

Figure 4. SVS elevations and U-series ages indicating times when RSL must have been lower, hence providing maximum RSL constraints. Note that continuous growth in some of these speleothems could provide more representative results. None of the data are corrected for GIA or long-term deformation.

Hence, they provide a unique opportunity to further enhance our knowledge on MIS 5 sea-level history, as presented below.

Obtaining 43 new U-series dates on POS from cave sites along the southern and eastern coasts of Majorca, Polyak et al. (2018) reported an accurate timing of MIS 5e sealevel history, with uncertainties of their U-Th ages better than \pm 500 years. The external elevation error within each cave is reported as $\pm 0.25 \mathrm{~m}$ and between all of the caves used in their study is reported to be $\pm 0.75 \mathrm{~m}$. Their results show that relative sea level in Majorca was $\sim 2.15 \pm$ $0.75 \mathrm{~m}$ above present level (m a.p.s.l.) between $126.6 \pm 0.4$ and $116 \pm 0.8 \mathrm{ka}$, although centennial-scale excursions cannot be excluded due to some small gaps in the POS record (Polyak et al., 2018). Similar encrustations were found in the Grotta di Nettuno, Capo Caccia, area (NW Sardinia, Italy), $\sim 500 \mathrm{~km}$ east of Majorca, but only one episode of high sea stand at $4.3 \mathrm{~m}$ a.p.s.l. was documented (Tuccimei et al., 2012). Polyak et al. (2018) attributed the discrepancy in RSL elevation between Sardinia and Majorca to minor differences in glacial isostatic adjustment and/or tectonic movement at the two sites. Given the large age uncertainties obtained using alpha counting and TIMS (see Fig. 3), it would be worth revisiting the chronology from Grotta di Nettuno and complementing it with more samples. Two POS-derived MIS 5e data from Majorca were also reported by Dorale et al. (2010) at $2.6 \mathrm{~m}$ a.p.s.l. in Cova des Pas de Vallgornera at 116.2 and $120.6 \mathrm{ka}$. Using younger POSs from the same and other caves, Dorale et al. (2010) showed that RSL in the western Mediterranean was at $\sim 1$ ma.p.s.l. during MIS 5a ( $\sim 81 \mathrm{ka}$ ), challenging the prevailing view of a much lower MIS 5a sea-level position. In summary, POSs are hence reliable and accurate indicators able to better resolve RSL during MIS 5.

Over 200 large POSs, out of which 24 were recently dated, occur in a limited altitudinal range of $\sim 40 \mathrm{~cm}$ in Santa Catalina Cave on the northern Cuban coast (De Waele et al., 2017, 2018). The authors suggest that the oldest age (126 ka, sample SC2.6a) is the most likely to reflect the chronology of the MIS 5e sea-level stand, while the younger ages (which show much higher initial uranium activity ratios) reflect recrystallization processes. The present-day elevation of these 24 POSs is at $16 \mathrm{~m}$ a.p.s.l. (De Waele et al., 2017). These samples formed during a time interval when the sea level was the highest, and the authors argue that slow uplift of the coastal area after their formation brought them to this elevation (De Waele et al., 2017, 2018). Additionally, these 24 POSs contributed to the reconstruction of the speleogenetic stages and the local coastal uplift, while also providing information on the sea-level variations during the last $\sim 400 \mathrm{ka}$. 


\subsection{SVS growth intervals - implications for sea-level upper bound estimates}

SVSs from submerged caves in tectonically stable areas provide an additional source of sea-level data, as their growth stops when rising sea levels flood the caves (Richards et al., 1994). The timing of initiation and cessation of speleothem growth is fairly easy to resolve applying U-Th measurements on carbonate material extracted from above and below a growth hiatus. The obtained ages will indicate when the cave was air-filled and when the cave was submerged (Li et al., 1989; Richards et al., 1994). One advantage of using SVSs is that they allow estimation of past low sea-level stands (lower than today) in both interglacial and glacial periods. Such information is especially critical in tectonically stable regions (e.g., Bahamas and parts of the Mediterranean Basin), where changes in sea level can be directly associated with changes in ice-sheet volume, which is a challenging task for sea-level indicators found in the uplifting coastline regions (e.g., Huon, Barbados, Haiti).

Submerged speleothems from Bermuda provide strong sea-level evidence and contribute notably to deciphering the timing of stillstands during MIS 5. The growth deposition of stalactites, stalagmites, and flowstones with low ${ }^{232} \mathrm{Th}$ content found in Bermudan caves indicates that sea level stood at $\sim 4$ to $6 \mathrm{~m}$ a.p.s.l. at $\sim 125 \mathrm{ka}$, it fell below $-6.5 \mathrm{~m}$ by $120 \mathrm{ka}$, and it stabilized for a short time at approximately $8 \mathrm{~m}$ below present at $\sim 114 \mathrm{ka}$ (Harmon et al., 1978). A few years later, another study by Harmon et al. (1981) using ages from submerged speleothems and eolianites showed that sea level at $\sim 105$ and $\sim 85 \mathrm{ka}$ was between -15 and $-20 \mathrm{~m}$ and at least $-15 \mathrm{~m}$ at $\sim 95 \mathrm{ka}$. Recent research on a submerged stalactite from Wilkinson Quarry Cave, northern Bermuda, indicates hiatuses starting at $137 \pm 5,106 \pm 6,84.3 \pm 1.5$, and $79.9 \pm 0.9 \mathrm{ka}$ (Wainer et al., 2017). These new results provide important constraints suggesting that local sea level might have peaked above $\sim 1.5 \mathrm{~m}$ a.p.s.l. during MIS 5e, $5 \mathrm{c}$, and $5 \mathrm{a}$. They also indicate a double highstand during MIS 5a, and while the data are in agreement with other studies from tectonically active regions (Surić et al., 2009), given the tectonic stability of Bermuda, Wainer et al. (2017) interpret the results as a global event associated with changes in ice-sheet volume and not a tectonic movement.

A large number of speleothems were collected from the Bahamian caves from different elevations as mentioned earlier in Sect. 2.1, but only a few of them captured sea-level stands during MIS 5. Spalding and Mathews (1972) first attempted to date SVSs from Grand Bahama Island and were followed by Gascoyne et al. (1979), Gascoyne (1984; northeastern coast of Andros and Lucayan Caverns, Grand Bahama), Richards et al. (1994; South Andros and Grand Bahama), and Smart et al. (1998; South Andros). Li et al. (1989) first presented ages on a flowstone collected from $-15 \mathrm{~m}$ below modern sea level in Lucayan Caverns, Grand Bahama Island, and documented hiatuses at a few different intervals including 133-110 and 100-97 ka. These ages were substantially improved by an order of magnitude using the TIMS method, and thus, sea level during MIS 5a was constrained to be below $-8.5 \mathrm{~m}$ (Lundberg and Ford, 1994) and between -15 and $-18 \mathrm{~m}$, as suggested by Richards et al. (1994). The latter study also precisely constrained the termination of MIS $5 \mathrm{a}$ by determining the age of a sample that started growth at $79.7 \pm 1.8 \mathrm{ka}$. More recently, Richards et al. (2012) revisited these estimates and applied the correction for non-bulk Earth initial ${ }^{230} \mathrm{Th} /{ }^{232} \mathrm{Th}$ contamination using the isochron method on samples of stalagmites from the same settings (Richards and Dorale, 2003). Stalagmites from a blue hole east of Andros Island were also sampled and dated for sealevel application. The first set of ages showed that some of these samples deposited during MIS 5; however, they were found to be out of stratigraphic order possibly due to incorporation of minor amounts of marine deposits surrounding the central core (Gascoyne et al., 1979). The authors eliminated the age-biasing marine deposits by progressive acid leaching of crushed samples and analyzed the cleaned calcite crystals, and the new results showed higher ages documenting a MIS 6 sea-level lowstand (at least $42 \mathrm{~m}$ below present level) between 160 and $139 \mathrm{ka}$ (Gascoyne et al., 1979).

Subaerial growth periods of speleothems from the Yucatán Peninsula provide precise and reliable maximum constraints for relative sea levels during MIS 5 that contribute to our understanding of sea level in the western North AtlanticCaribbean region (Moseley et al., 2013). The authors show that following the MIS 5e highstand, RSL dropped below $-4.9 \mathrm{~m}$ by $117.7 \pm 1.4 \mathrm{ka}$. They also provide maximum sealevel stands during MIS 5c and 5a: (i) MIS 5c sea-level highstand occurred after $107.7 \pm 0.9 \mathrm{ka}$ between -11 and $-4.9 \mathrm{~m}$ and ended by $108.2 \pm 4.9 \mathrm{ka}$, and (ii) sea level peaked during MIS 5a after $87.6 \pm 0.6 \mathrm{ka}$ at an elevation higher than $-9.9 \mathrm{~m}$, but the length of this highstand is poorly constrained because of the high detrital Th in the speleothem. Sea level then dropped below $-14.6 \mathrm{~m}$, and the speleothem continued to grow until $61.3 \pm 0.4 \mathrm{ka}$. In addition to the information provided on the maximum RSL, when speleothems with precise ages are used in conjunction with data from other local sealevel indicators, they can also offer robust chronologies for the timing of the relative sea-level fall at the last interglacial termination (Moseley et al., 2013).

Constraints on the maximum RSL during MIS 5a in the eastern Mediterranean basin are provided by Surić et al. (2009), who dated two submerged stalagmites from the U Vode Pit on Krk Island, in the eastern Adriatic Sea. Their double-highstand MIS 5a sea-level scenario is supported by layers of halite and gypsum associated with hiatuses in speleothem growth probably caused by seawater inundation. The timing of possible marine incursions was determined by dating the layers below and above these growth hiatuses. Their work was further continued by Surić and Juračić (2010), who investigated 16 submerged speleothems from seven submarine caves and pits along the eastern Adri- 
atic coast to provide insight into the sea-level changes over the last $220 \mathrm{kyr}$.

Reconstructions of MIS 5e sea-level evolution are also provided by stratigraphical and geochronological constraints from Infreschi Cave (Marina di Camerota, Italy). A combination of U-Th ages of speleothem deposition phases with ages of calcite in Lithophaga boreholes and with ${ }^{40} \mathrm{Ar} /{ }^{39} \mathrm{Ar}$ ages of correlated tephra indicates that sea level fell more than $6 \mathrm{~m}$ before $\sim 120 \mathrm{ka}$ and places the maximum highstand RSL at $8.90 \pm 0.6 \mathrm{~m}$ a.p.s.l. (Bini et al., 2020).

\subsection{POS- and SVS-derived sea level provides inputs for glacial isostatic adjustment models}

The recorded elevations of sea-level indicators reflect a combination of local changes in sea level of a region due to glacial isostatic adjustment that causes land uplift or subsidence, displacing the local sea-level datum relative to the global mean (Rovere et al., 2016b). Thus, a significant part of the spatial variation in the MIS 5 sea-level record is due to the diverse response of coastlines to GIA, depending on the extent of continental or insular shelves, the distance from former ice sheets, and other variables (Dutton and Lambeck, 2012; Creveling et al., 2015; Dendy et al., 2017). Consequently, interpreting local sea-level markers first involves understanding and correcting for the ongoing effects of GIA. Numerical models generally estimate GIA with assumptions about the thickness, distribution, extension, and duration of former ice loads as well as the viscoelastic properties of Earth (Mitrovica and Milne, 2003; Austermann et al., 2017). The speleothems from locations such as Majorca, Bermuda, the Bahamas, and the Yucatán Peninsula provide an additional and independent source of sea-level data, which have the potential to provide valuable information about the deformation parameters of the Earth and about the distribution of past ice sheets. Their distance from large pre-existing ice sheets and relatively stable passive margin tectonic setting is what makes them ideal locations.

The high-resolution POS-derived sea-level record from Majorca was corrected to estimate the ice-equivalent sea level by using nine different GIA models (Polyak et al., 2018). The authors' preferred model showed that in Majorca sea level peaked early in the MIS 5e at $5 \mathrm{~m}$ a.p.s.l. due to the proximity to the forebulge of the penultimate glacial maximum (PGM) Eurasian Ice Sheet and then gradually decreased and stabilized by $122 \mathrm{ka}$ at $2.15 \pm 0.75 \mathrm{~m}$, until the highstand termination at $116 \mathrm{ka}$. None of their models support the hypothesis of a second highstand during MIS 5e, and their results show no evidence for rapid sea-level fluctuations larger than $1 \mathrm{~m}$. They also suggested that the corrected sea level is more sensitive to the size and distribution of the Northern Hemisphere PGM ice sheets than to the one-dimensional Earth model used for other predictions. This record allowed the authors to test both the sensitivity of MIS 5e sea-level stand predicted by GIA models to PGM ice distribution and the timing of deglaciation (Polyak et al., 2018).

Bermuda is strongly affected by the glacial forebulge that forms due to the presence of the Laurentide Ice Sheet during glacial periods (Harmon et al., 1981, 1978; Wainer et al., 2017); hence sea-level markers from this location have the potential to capture the response of the forebulge to glacial loading and can be seen as gauges. Based on U-Th ages of SVSs from Wilkinson Quarry Cave, Bermuda, Wainer et al. (2017) showed that RSL was higher than $1.5 \pm 0.5 \mathrm{~m}$ during MIS 5e, MIS 5c, and MIS 5a. The results also suggest a double RSL peak during MIS 5a, indicating rapid sea-level variation associated with changes in ice-sheet volume. Testing GIA models against these new constraints, the results reinforce the presence of a smaller Laurentide Ice Sheet during late MIS 5 and a restricted range of Earth viscosity values, with higher values of lower-mantle viscosity compared to those used in some GIA models (e.g., Creveling et al., 2017). Wainer et al. (2017) confirm that it is possible to explain a wide range of MIS 5c-a relative sea levels observed across the western North Atlantic-Caribbean in GIA models, even with a limited range of mantle deformation constants.

The Bahamas Archipelago spans the southeastern edge of the peripheral bulge of the ancient Laurentide ice complex, and hence this is a region that captures gradients in the GIA prediction. The majority of reconstructed MIS 5 sea-level estimates in the Bahamas use corals (Chen et al., 1991; Thompson et al., 2011; Skrivanek et al., 2018; Muhs et al., 2020). While these records demonstrate the potential of this area for sea-level reconstruction, despite the data abundance, the precision of the inferred water depth and also the open-system U-series behavior of some corals cast uncertainty on existing RSL estimates. Undoubtedly, the uncertainties behind GIA corrections and the models that investigators adopted also lower the accuracy of the reconstructed sea level. In addition to the GIA corrections, the long-term subsidence of the platform also needs to be considered when assessing the last interglacial sea-level record. Subsurface drill core data from shallow-water stacked facies indicate that the Bahamas is subsiding at rates of several meters per $100 \mathrm{kyr}$ (McNeill, 2005). None of the Bahamian cave deposits reported so far (Gascoyne et al., 1979; Gascoyne, 1984; Lundberg and Ford, 1994; Richards et al., 1994; Smart et al., 1998) address these corrections, but observations indicate the abundance of this type of sea-level indicator and its potential to provide additional data to help decipher the duration and amplitude of last interglacial sea level in this region.

Moseley et al. (2013) used SVS growth periods to constrain maximum elevations of relative sea level, which are in agreement with GIA models for the near to intermediate region of the former North American Ice Sheet. Based on GIA modeling, Lambeck et al. (2012) classified the Yucatán Peninsula as a near-field site in the western North AtlanticCaribbean region located on the deformational bulge; thus, its MIS 5 sea-level indicators are affected by significant GIA 
effects. Moseley et al. (2013) provide additional constraints on the timing of sea-level fall following the MIS 5e highstand and on sea-level peaks during MIS $5 \mathrm{c}$ and $5 \mathrm{a}$, indicating that a second MIS 5a highstand did not reach as high as the first in the Yucatán. The authors highlight the challenges of comparing sea-level records from the Yucatán Peninsula with data even from other field sites in the western North Atlantic-Caribbean region due to the complexity of estimating the GIA effects. They also emphasize the need for improved estimates of the MIS 5 sea-level highstand in the Yucatán in order to better constrain the sea-level history that can be used in predictive GIA modeling studies.

Altogether, both POS and SVS provide powerful constraints for future GIA models and also help refine ice-sheet histories and solid Earth properties. The geological data can test the GIA models, which will lead to an improvement of the modeled MIS 5 sea-level elevations for a large number of localities around the world.

\subsection{POS- and SVS-derived sea level registers tectonic uplift rates}

Long-term deformation (uplift or subsidence) can substantially affect the speleothem-derived sea-level results. Assessing POS ages and their elevations and knowing their clear relation to sea level proved to be a useful tool in estimating past tectonic evolution of the regional coastal karst landscape (Fornós et al., 2002; De Waele et al., 2018; Dumitru et al., 2019).

Using U-Th data from Vesica et al. (2000), Fornós et al. (2002) suggested some tectonic tilting (increasing elevations northwards) in the eastern part of Majorca based on POS horizons dated at MIS 5e, 5c, and 5a. They estimated an average minimum velocity of the tilting of $\sim 0.02 \mathrm{~mm} \mathrm{yr}^{-1}$ in the southern part with respect to the north. However, more recent higher-resolution $\mathrm{U}-\mathrm{Th}$ results with better analytical precision and also more accurate elevation measurements provide evidence for tectonic stability of the region from MIS 9 to the present (Dorale et al., 2010; Polyak et al., 2018). This evidence is based on the presence of multiple highstands within the same cave indicated by different POS horizons, which suggest that RSL remained within the vertical extent of the cave over time (1.1 ma.p.s.l. during MIS 9, $2.15 \mathrm{~m}$ a.p.s.l. during MIS 5e, and $1.42 \mathrm{~m}$ a.s.p.l. during MIS 5a; Dorale et al., 2010; Polyak et al., 2018). A more recent study has confirmed the tectonic stability of Majorca based on the observed elevation of six Pliocene POSs and estimated a median uplift rate at this site of $0.002 \mathrm{~mm} \mathrm{yr}^{-1}(0.0006-$ $0.0044 \mathrm{~m} \mathrm{Myr}^{-1}$; Dumitru et al., 2019).

POSs sampled from Cuba reveal Upper PleistoceneHolocene coastal uplift rates at Matanzas between 0.05 and $0.10 \mathrm{~mm} \mathrm{yr}^{-1}$ (De Waele et al., 2017), 1 order of magnitude lower than those reported previously based on geodetic measurements along various parts of the Cuban coastline (Iturralde-Vinent, 2003). These results confirm the lower up- lift rates of the western part of Cuba compared with the eastern sectors and argue that uplift rates are site-specific (De Waele et al., 2017). De Waele et al. (2018) further show that coastal uplift of Cuba has varied widely over the last $600-400 \mathrm{kyr}$, with no uplift or even periods of slow subsidence that characterized the MIS 11-MIS 5e time frame. Data also allowed the placement of these stages in a broader regional context of uplift and sea-level variations during the last $\sim 400 \mathrm{kyr}$.

The SVSs collected from Croatia indicate a MIS 5a sealevel stand of at least $-14 \mathrm{~m}$ (Surić et al., 2009); however, the authors acknowledge that these results would most likely need to be corrected for long-term regional tectonic uplift of $0.15-0.25 \mathrm{~mm} \mathrm{yr}^{-1}$ with episodical subsidence events generated by collision of the Adria microplate with the Eurasian Plate (Surić et al., 2009). If other model evidence is assumed, these results can put constraints on temporal uplift.

\section{Data availability}

The speleothems database is available with open access and periodically updated as needed, at the following link: https://doi.org/10.5281/zenodo.4313860 (Dumitru et al., 2020). The description of each field in the database can be found at https://doi.org/10.5281/zenodo.3961544 (Rovere et al., 2020). More information on the World Atlas of Last Interglacial Shorelines can be found at https://warmcoasts.eu/ world-atlas.html (last access: 12 April 2021). Users of our database are encouraged to cite the original sources alongside our database and this article.

\section{Concluding remarks and future directions}

This dataset paper represents the first compilation of speleothem-derived (POSs as sea-level index points and SVSs as terrestrial limiting points) sea-level history for the last interglacial period. The purpose of this work is to contextualize the interpretation of speleothem records in a framework that would facilitate the MIS 5 sea-level research community to use the worldwide database. Littoral caves offer a means of addressing the temporal and spatial sea-level data gaps in other proxies, by hosting deposits which provide an opportunity to independently date records of past sea-level changes. The phreatic overgrowth mechanism that deposits calcite/aragonite at sea level arguably provides the most precise and less ambiguous indicator of RSL timing and elevation. Intervals of SVS growth are indicative of times when sea level must have been lower than their elevation. Hiatuses can also be used to indicate sea-level position; however, they must be cautiously interpreted since there are several reasons that cause their occurrence. Hiatuses associated with biogenic encrustations or borings could potentially indicate more exactly where sea level was with respect to the SVS. Speleothems from locations such as Majorca, Bermuda, the 
Bahamas, and the Yucatán Peninsula are particularly useful, not only for the information they provide about the eustatic sea level but more importantly for the critical constraints on future GIA models to help refine ice-sheet loads and regional mantle rheology. These records of sea level from low-lying islands and continental coastlines could benefit research related to other disciplines, such as water resource availability, sea-level rise projections, and saltwater intrusions.

Our contribution to the WALIS database should be seen as a highlighting point on the relevance of speleothems for sealevel studies. In this compiled database on MIS 5 sea level, we list the areas where these sea-level indicators are located and identify future research priorities. One research direction could be exploring for additional POS levels from Sardinia, which in conjunction with the extensive POS data from Majorca would provide relevant information for better GIA and tectonic context for the western Mediterranean Basin. Another direction could be sampling and dating the stalagmites identified at elevations much lower than present sea level in caves from the Bahamas and Bermuda; their chronologies can contribute to an improved record of low sea-level stands during the Pleistocene. Of equal priority is to re-analyze the samples that have been dated by means of alpha spectrometry, using the more advanced facilities in order to increase the precision of the ages. Of great importance is exploring new locations for additional POSs or SVSs along continental and island carbonate coastlines that would complement the already existing records.

To build a more valuable dataset that will be used across different disciplines, we strongly encourage researchers publishing new sea-level studies based on speleothems to include the following information.

- Sea-level indicator and its relationship to sea level. (i) Site location (latitude and longitude of the cave); (ii) the elevation of the sea-level indicator, the instrument type used and its precision, and the error associated with the elevation measurement (when using barometric altimeter or diver depth gauge for submerged samples, the elevations should be adjusted for density variation in the water column whenever salinity profiles are available, and the vertical density profile associated with freshwater, brackish, and saline zones should be included with the depth information); and (iii) the sealevel datum to which the elevations are referred and how the indicative meaning has been quantified.

- Screening results. XRD, petrography, and polarizing/scanning electron imaging, including information on mineral assemblage, as well as diagenetic and crystallization descriptions (e.g., fabric).

- U-series data. In order to collectively improve the utility of U-series data, we encourage researchers publishing new speleothem-based sea-level studies to follow the recommendations suggested by Dutton et al. (2017) in reporting their data. These authors specify the required data to enable calculation and, if needed, recalculation of the same ages using different parameters and also to facilitate the interpretation in the context of other studies. The checklist of minimum data to report includes uncertainties for all parameters, whether uncertainties on ages include decay-constant uncertainties; names, descriptions, and reference values of reference materials; decay constants; isotopes in spike and method of spike calibration; method of calibration for all activity or atom ratios reported; activity or atom ratios for ${ }^{230} \mathrm{Th} /{ }^{238} \mathrm{U}$ (or ${ }^{230} \mathrm{Th} /{ }^{234} \mathrm{U}$ ) and ${ }^{234} \mathrm{U} /{ }^{238} \mathrm{U}$; ${ }^{230} \mathrm{Th} /{ }^{232} \mathrm{Th}$ activity or atom ratio; details of procedures and values used to interpret ages using isochrons or other models; and date of analysis or reference age (e.g., BP, b2k). These recommendations will increase the usefulness of this type of analytical result in the Useries geochronology community (Dutton et al., 2017). We also recommend reporting growth rate, which allows a better definition of the onset and cessation of deposition for either POS or SVS samples.

Author contributions. OAD compiled the data and drafted and wrote the manuscript with input from BPO, VP, and YA. BPO contributed to designing the figures, and VP and YA provided expert reviews of U-series data.

Competing interests. The authors declare that they have no conflict of interest.

Special issue statement. This article is part of the special issue "WALIS - the World Atlas of Last Interglacial Shorelines". It is not associated with a conference.

Acknowledgements. The data used in this study were compiled in WALIS, a sea-level database interface developed by the ERC Starting Grant "WARMCOASTS" (ERC-StG-802414), in collaboration with the PALSEA (PAGES/INQUA) working group. The database structure was designed by Alessio Rovere, Dierdre Ryan, Thomas Lorscheid, Andrea Dutton, Peter Chutcharavan, Dominik Brill, Nathan Jankowski, Daniela Mueller, Melanie Bartz, Evan Gowan, and Kim Cohen. The data points used in this study were contributed to WALIS by Oana-Alexandra Dumitru, WALIS Admin, Alessio Rovere, Ann-Kathrin Petersen, and Deirdre Ryan (in order of numbers of records inserted). We thank Vanessa Johnston, David Richards, and the anonymous reviewer for their careful feedback and useful recommendations. Special thanks go to Alessio Rovere for his guidance and assistance in the data compilation and manuscript preparation. We also thank Joyce Lundberg for providing the elevation information on the samples from the McMaster collection. We acknowledge Joan Fornós, Angel Ginés, and Joaquin Ginés for development of the POS model. 
Financial support. Part of the data included in the database results were generated by a collaborative NSF grant (AGS 1602670 and 1602685) to Bogdan P. Onac and Victor J. Polyak.

Review statement. This paper was edited by Alessio Rovere and reviewed by David Richards, Vanessa Johnston, and one anonymous referee.

\section{References}

Antonioli, F., Bard, E., Potter, E.-K., Silenzi, S., and Improta, S.: $215 \mathrm{ka}$ History of sea-level oscillations from marine and continental layers in Argentarola Cave speleothems (Italy), Global Planet. Change, 43, 57-78, https://doi.org/10.1016/j.gloplacha.2004.02.004, 2004.

Antonioli, F., Lo Presti, V., Rovere, A., Ferranti, L., Anzidei, M., Furlani, S., Mastronuzzi, G., Orru, P. E., Scicchitano, G., Sannino, G., Spampinato, C. R., Pagliarulo, R., Deiana, G., de Sabata, E., Sansò, P., Vacchi, M., and Vecchio, A.: Tidal notches in Mediterranean Sea: a comprehensive analysis, Quaternary Sci. Rev., 119, 66-84, https://doi.org/10.1016/j.quascirev.2015.03.016, 2015.

Antonioli, F., Furlani, S., Montagna, P., and Stocchi, P.: The Use of Submerged Speleothems for Sea Level Studies in the Mediterranean Sea: A New Perspective Using Glacial Isostatic Adjustment (GIA), Geosciences, 11, 77, https://doi.org/10.3390/geosciences11020077, 2021.

Arienzo, M. M., Swart, P. K., Pourmand, A., Broad, K., Clement, A. C., Murphy, L. N., Vonhof, H. B., and Kakuk, B.: Bahamian speleothem reveals temperature decrease associated with Heinrich stadials, Earth Planet. Sc. Lett., 430, 377-386, https://doi.org/10.1016/j.epsl.2015.08.035, 2015.

Arienzo, M. M., Swart, P. K., Broad, K., Clement, A. C., Pourmand, A., and Kakuk, B.: Multi-proxy evidence of millennial climate variability from multiple Bahamian speleothems, Quaternary Sci. Rev., 161, 18-29, https://doi.org/10.1016/j.quascirev.2017.02.004, 2017.

Atsawawaranunt, K., Comas-Bru, L., Amirnezhad Mozhdehi, S., Deininger, M., Harrison, S. P., Baker, A., Boyd, M., Kaushal, N., Ahmad, S. M., Ait Brahim, Y., Arienzo, M., Bajo, P., Braun, K., Burstyn, Y., Chawchai, S., Duan, W., Hatvani, I. G., Hu, J., Kern, Z., Labuhn, I., Lachniet, M., Lechleitner, F. A., Lorrey, A., Pérez-Mejías, C., Pickering, R., Scroxton, N., and SISAL Working Group Members: The SISAL database: a global resource to document oxygen and carbon isotope records from speleothems, Earth Syst. Sci. Data, 10, 1687-1713, https://doi.org/10.5194/essd-10-1687-2018, 2018.

Austermann, J., Mitrovica, J. X., Huybers, P., and Rovere, A.: Detection of a dynamic topography signal in last interglacial sea-level records, Science Advances, 3, e1700457, https://doi.org/10.1126/sciadv.1700457, 2017.

Baeza, E., Lozano, R. P., and Rossi, C.: Replication and reinsertion of stalagmites sampled for paleoclimatic purposes, Int. J. Speleol., 47, 137-144, https://doi.org/10.5038/1827806X.47.2.2183, 2018.

Bajo, P., Hellstrom, J., Frisia, S., Drysdale, R., Black, J., Woodhead, J., Borsato, A., Zanchetta, G., Wallace, M. W., Regattieri,
E., and Haese, R.: "Cryptic" diagenesis and its implications for speleothem geochronologies, Quaternary Sci. Rev., 148, 17-28, https://doi.org/10.1016/j.quascirev.2016.06.020, 2016.

Beck, J. W., Richards, D. A., Edwards, R. L., Silverman, B. W., Smart, P. L., Donahue, D. J., Hererra-Osterheld, S., Burr, G. S., Calsoyas, L., Jull, A. J. T., and Biddulph, D.: Extremely large variations of atmospheric ${ }^{14} \mathrm{C}$ concentration during the Last Glacial Period, Science, 292, 2453-2458, https://doi.org/10.1126/science.1056649, 2001.

Benjamin, G. J.: Diving into the Blue Holes of the Bahamas, Natl. Geogr., 138, 347-363, 1970.

Bini, M., Isola, I., Pappalardo, M., Ribolini, A., Favalli, M., Ragaini, L., and Zanchetta, G.: Abrasive notches along the Atlantic Patagonian coast and their potential use as sea level markers: the case of Puerto Deseado (Santa Cruz, Argentina), Earth Surf. Proc. Land., 39, 1550-1558, https://doi.org/10.1002/esp.3612, 2014.

Bini, M., Zanchetta, G., Drysdale, R. N., Giaccio, B., Stocchi, P., Vacchi, M., Hellstrom, J. C., Couchoud, I., Monaco, L., Ratti, A., Martini, F., and Sarti, L.: An end to the Last Interglacial highstand before $120 \mathrm{ka}$ : Relative sea-level evidence from Infreschi Cave (Southern Italy), Quaternary Sci. Rev., 250, 106658, https://doi.org/10.1016/j.quascirev.2020.106658, 2020.

Bontognali, T. R. R., D’Angeli, I. M., Tisato, N., Vasconcelos, C., Bernasconi, S. M., Gonzales, E. R. G., and De Waele, J.: Mushroom Speleothems: Stromatolites That Formed in the Absence of Phototrophs, Front. Earth Sci., 4, 49, https://doi.org/10.3389/feart.2016.00049, 2016.

Boop, L. M., Onac, B. P, Wynn, J. G., Fornós, J. J., RodríguezHomar, M., and Merino, A.: Groundwater geochemistry observations in littoral caves of Mallorca (western Mediterranean): implications for deposition of phreatic overgrowths on speleothems, Int. J. Speleol., 43, 193-203, 2014.

Capron, E., Rovere, A., Austermann, J., Axford, Y., Barlow, N. L. M., Carlson, A. E., de Vernal, A., Dutton, A., Kopp, R. E., McManus, J. F., Menviel, L., Otto-Bliesner, B. L., Robinson, A., Shakun, J. D., Tzedakis, P. C., and Wolff, E. W.: Challenges and research priorities to understand interactions between climate, ice sheets and global mean sea level during past interglacials, Quaternary Sci. Rev., 219, 308-311, https://doi.org/10.1016/j.quascirev.2019.06.030, 2019.

Carew, J. L. and Mylroie, J. E.: Quaternary tectonic stability of the Bahamian Archipelago: Evidence from fossil coral reefs and flank margin caves, Quaternary Sci. Rev., 14, 144-153, 1995.

Chen, J. H., Curran, H. A., White, B., and Wasserburg, G. J.: Precise chronology of the last interglacial period: ${ }^{234} \mathrm{U}_{-}{ }^{230} \mathrm{Th}$ data from fossil coral reefs in the Bahamas, Geol. Soc. Am. Bull., 103, 8297, 1991.

Cheng, H., Edwards, R. L., Hoff, J., Gallup, C. D., Richards, D. A., and Asmerom, Y.: The half-lives of uranium-234 and thorium230, Chem. Geol., 169, 17-33, https://doi.org/10.1016/S00092541(99)00157-6, 2000.

Cheng, H., Edwards, R. L., Shen, C.-C., Polyak, V. J., Asmerom, Y., Woodhead, J., Hellstrom, J., Wang, Y., Kong, X., Spötl, C., Wang, X., and Calvin Alexander, E.: Improvements in ${ }^{230} \mathrm{Th}$ dating, ${ }^{230} \mathrm{Th}$ and ${ }^{234} \mathrm{U}$ half-life values, and $\mathrm{U}-\mathrm{Th}$ isotopic measurements by multi-collector inductively coupled plasma mass spectrometry, Earth Planet. Sc. Lett., 371-372, 82-91, https://doi.org/10.1016/j.eps1.2013.04.006, 2013. 
Chutcharavan, P. M. and Dutton, A.: A Global Compilation of Useries Dated Fossil Coral Sea-level Indicators for the Last Interglacial Period (MIS 5e), Earth Syst. Sci. Data Discuss. [preprint], https://doi.org/10.5194/essd-2020-381, in review, 2020.

Comas-Bru, L., Rehfeld, K., Roesch, C., Amirnezhad-Mozhdehi, S., Harrison, S. P., Atsawawaranunt, K., Ahmad, S. M., Brahim, Y. A., Baker, A., Bosomworth, M., Breitenbach, S. F. M., Burstyn, Y., Columbu, A., Deininger, M., Demény, A., Dixon, B., Fohlmeister, J., Hatvani, I. G., Hu, J., Kaushal, N., Kern, Z., Labuhn, I., Lechleitner, F. A., Lorrey, A., Martrat, B., Novello, V. F., Oster, J., Pérez-Mejías, C., Scholz, D., Scroxton, N., Sinha, N., Ward, B. M., Warken, S., Zhang, H., and SISAL Working Group members: SISALv2: a comprehensive speleothem isotope database with multiple age-depth models, Earth Syst. Sci. Data, 12, 2579-2606, https://doi.org/10.5194/essd-12-25792020, 2020.

Creveling, J. R., Mitrovica, J. X., Clark, P. U., Waelbroeck, C., and Pico, T.: Predicted bounds on peak global mean sea level during marine isotope stages 5a and 5c, Quaternary Sci. Rev., 163, 193208, https://doi.org/10.1016/j.quascirev.2017.03.003, 2017.

Csoma, A. E., Goldstein, R.H., and Pomar, L.: Pleistocene speleothems of Mallorca; implications for palaeoclimate and carbonate diagenesis in mixing zones, Sedimentology, 53, 213-236, 2006.

De Waele, J., D’Angeli, I. M., Tisato, N., Tuccimei, P., Soligo, M., Ginés, J., Ginés, A., Fornós, J. J., Villa, I. M., Grau González, E. R., Bernasconi, S. M., and Bontognali, T. R. R.: Coastal uplift rate at Matanzas (Cuba) inferred from MIS5e phreatic overgrowths on speleothems, Terra Nova, 29, 98-105, https://doi.org/10.1111/ter.12253, 2017.

De Waele, J., D’Angeli, I. M., Bontognali, T., Tuccimei, P., Scholz, D., Jochum, K. P., Columbu, A., Bernasconi, S. M., Fornós, J. J., Grau González, E. R., and Tisato, N.: Speleothems in a north Cuban cave register sea-level changes and Pleistocene uplift rates, Earth Surf. Proc. Land., 43, 2313-2326, https://doi.org/10.1002/esp.4393, 2018.

Dendy, S., Austermann, J., Creveling, J. R., and Mitrovica, J. X.: Sensitivity of Last Interglacial sea-level high stands to ice sheet configuration during Marine Isotope Stage 6, Quaternary Sci. Rev., 171, 234-244, https://doi.org/10.1016/j.quascirev.2017.06.013, 2017.

Dorale, J. A., Onac, B. P., Fornós, J. J., Ginés, J., Ginés, A., Tuccimei, P., and Peate, D. W.: Sea-Level highstand 81000 years ago in Mallorca, Science, 327, 860-863, https://doi.org/10.1126/science.1181725, 2010.

Dumitru, O. A., Austermann, J., Polyak, V. J., Fornos, J. J., Asmerom, Y., Ginés, J., Ginés, A., and Onac, B. P.: Constraints on global mean sea level during Pliocene warmth, Nature, 574, 233236, https://doi.org/10.1038/s41586-019-1543-2, 2019.

Dumitru, O. A., Polyak, V. P., Asmerom, Y., and Onac, B. P.: A global standardized database of Last Interglacial (sensu lato, $\sim 130$ to $75 \mathrm{ka}$ ) sea level records from U-series dated cave deposits, Zenodo, https://doi.org/10.5281/zenodo.4313861, 2020.

Dumitru, O. A., Austermann, J., Polyak, V. J., Fornoìs, J. J., Asmerom, Y., Gineìs, J., Gineìs, A., and Onac, B. P.: Sea-level stands from the Western Mediterranean over the past 6.5 million years, Sci. Rep., 11, 261, https://doi.org/10.1038/s41598020-80025-6, 2021.
Dutton, A. and Lambeck, K.: Ice volume and sea level during the Last Interglacial, Science, 337, 216-219, https://doi.org/10.1126/science.1205749, 2012.

Dutton, A., Bard, E., Antonioli, F., Esat, T. M., Lambeck, K., and McCulloch, M. T.: Phasing and amplitude of sea-level and climate change during the penultimate interglacial, Nat. Geosci., 2, 355-359, https://doi.org/10.1038/ngeo470, 2009.

Dutton, A., Rubin, K., McLean, N., Bowring, J., Bard, E., Edwards, R. L., Henderson, G. M., Reid, M. R., Richards, D. A., Sims, K. W. W., Walker, J. D., and Yokoyama, Y.: Data reporting standards for publication of U-series data for geochronology and timescale assessment in the earth sciences, Quat. Geochronol., 39, 142149, https://doi.org/10.1016/j.quageo.2017.03.001, 2017.

Edwards, R. L., Chen, J. H., Ku, T. L., and Wasserburg, G. J.: Precise timing of the Last Interglacial Period from mass spectrometric determination of Thorium-230 in corals, Science, 236, 15471553, https://doi.org/10.1126/science.236.4808.1547, 1987.

Fornós, J. J., Gelabert, B., Ginés, A., Ginés, J., Tuccimei, P., and Vesica, P.: Phreatic overgrowths on speleothems: a useful tool in structural geology in littoral karstic landscapes. The example of eastern Mallorca (Balearic Islands), Geodin. Acta, 15, 113-125, https://doi.org/10.1080/09853111.2002.10510745, 2002.

Frappier, A. B.: A stepwise screening system to select storm-sensitive stalagmites: Taking a targeted approach to speleothem sampling methodology, Quatern. Int., 187, 25-39, https://doi.org/10.1016/j.quaint.2007.09.042, 2008.

Gascoyne, M.: Uranium-series ages of speleothems from Bahaman blue holes and their significance, British Cave Research Association, Somerset, Bridgwater, UK, 45-49, 1984.

Gascoyne, M., Benjamin, G. J., Schwarz, H. P., and Ford, D. C.: Sea-level lowering during the Illinoian Glaciation: Evidence from a Bahama "Blue Hole", Science, 205, 806-808, 1979.

Ginés, A. and Ginés, J.: Consideraciones sobre los mecanismos de fosilización de la Cova de sa Bassa Blanca y su paralelismo con formaciones marinas del Cuaternario, Boletín de la Sociedad de Historia Natural de Baleares, 19, 11-28, 1974.

Ginés, J., Fornós, J. J., and Ginés, A.: Els espeleotemes freàtics del Quaternari de Mallorca: aspectes morfològics, mineralògics i cristal-logràfics, in: Geomorfologia litoral i Quaternari.: Homenatge al professor Vicenç M. Rosselló i Verger, edited by: Sanjaume, E. and Mateu, J. F., Universitat de València, València, Spain, 151-165, 2005.

Ginés, J., Ginés, A., Fornós, J. J., Tuccimei, P., Onac, B. P., and Gràcia, F. (Eds.): Phreatic overgrowths on speleothems (POS) from Mallorca: updating forty years of research, in: Mallorca: a Mediterranean benchmark for Quaternary studies, Monografies de la Societat d'Historia Natural de les Balears, 111-146, 2012.

Grimes, K. G.: Karst features of Christmas Island (Indian Ocean), Helictite, 37, 41-58, 2001.

Harmon, R. S., Schwarcz, H. P., and Ford, D. C.: Late Pleistocene sea level history of Bermuda, Quaternary Res., 9, 205218, https://doi.org/10.1016/0033-5894(78)90068-6, 1978.

Harmon, R. S., Land, L. S., Mitterer, R. M., Garrett, P., Schwarcz, H. P., and Larson, G. J.: Bermuda sea level during the last interglacial, Nature, 289, 481-483, https://doi.org/10.1038/289481a0, 1981.

Hellstrom, J.: U-Th dating of speleothems with high initial ${ }^{230} \mathrm{Th}$ using stratigraphical constraint, Quat. Geochronol., 1, 289-295, https://doi.org/10.1016/j.quageo.2007.01.004, 2006. 
Hibbert, F. D., Rohling, E. J., Dutton, A., Williams, F. H., Chutcharavan, P. M., Zhao, C., and Tamisiea, M. E.: Coral indicators of past sea-level change: A global repository of U-series dated benchmarks, Quaternary Sci. Rev., 145, 1-56, https://doi.org/10.1016/j.quascirev.2016.04.019, 2016.

Hoffmann, D. L., Prytulak, J., Richards, D. A., Elliott, T., Coath, C. D., Smart, P. L., and Scholz, D.: Procedures for accurate $U$ and Th isotope measurements by high precision MC-ICPMS, Int. J. Mass Spectrom., 264, 97-109, https://doi.org/10.1016/j.ijms.2007.03.020, 2007.

Hoffmann, D. L., Beck, J. W., Richards, D. A., Smart, P. L., Singarayer, J. S., Ketchmark, T., and Hawkesworth, C. J.: Towards radiocarbon calibration beyond $28 \mathrm{ka}$ using speleothems from the Bahamas, Earth Planet. Sc. Lett., 289, 1-10, https://doi.org/10.1016/j.epsl.2009.10.004, 2010.

Hoffmann, D. L., Standish, C. D., García-Diez, M., Pettitt, P. B., Milton, J. A., Zilhão, J., Alcolea-González, J. J., CantalejoDuarte, P., Collado, H., de Balbín, R., Lorblanchet, M., RamosMuñoz, J., Weniger, G. C., and Pike, A. W. G.: U-Th dating of carbonate crusts reveals Neandertal origin of Iberian cave art, Science, 359, 912-915, https://doi.org/10.1126/science.aap7778, 2018.

Hopley, D.: Beachrock as sea-level indicator, in: Sea-level research: A manual for the collection and evaluation of data, edited by: Plassche, V. D., Springer Netherlands, 1986.

Iturralde-Vinent, M. A.: Ensayo sobre la paleogeografía del Cuaternario de Cuba, in: V. Congreso de Geología y Minería, Geología del Cuaternario, Geomorfología y Carso, La Habana, 2428 March 2003, 54-74, 2003.

Jaffey, A. H., Flynn, K. F., Glendenin, L. E., Bentley, W. C., and Essling, A. M.: Precision measurement of half-lives and specific activities of ${ }^{235} \mathrm{U}$ and ${ }^{238} \mathrm{U}$, Phys. Rev. C, 4, 1889-1906, 1971.

Jenson, A., Schwartz, B. F., Li, Y., and Gao, Y.: The implications and limitations of phreatic overgrowths of speleothems as sea level indicators: Quintana Roo, Mexico, in: 130th GSA Annual Meeting, Indianapolis, Indiana, USA, Geological Society of America (GSA), 4-7 November 2018, https://doi.org/10.1130/abs/2018AM-318501, Paper No. 147-6, 2018.

Khan, N. S., Horton, B. P., Engelhart, S., Rovere, A., Vacchi, M., Ashe, E. L., Törnqvist, T. E., Dutton, A., Hijma, M. P., and Shennan, I.: Inception of a global atlas of sea levels since the Last Glacial Maximum, Quaternary Sci. Rev., 220, 359-371, https://doi.org/10.1016/j.quascirev.2019.07.016, 2019.

Kopp, R. E., Simons, F. J., Mitrovica, J. X., Maloof, A. C., and Oppenheimer, M.: Probabilistic assessment of sea level during the last interglacial stage, Nature, 462, 863-867, https://doi.org/10.1038/nature08686, 2009.

Lachniet, M. S., Bernal, J. P., Asmerom, Y., and Polyak, V. J.: Uranium loss and aragonite-calcite age discordance in a calcitized aragonite stalagmite, Quat. Geochronol., 14, 26-37, https://doi.org/10.1016/j.quageo.2012.08.003, 2012.

Lambeck, K., Purcell, A., and Dutton, A.: The anatomy of interglacial sea levels: The relationship between sea levels and ice volumes during the Last Interglacial, Earth Planet. Sc. Lett., 315, 4-11, https://doi.org/10.1016/j.epsl.2011.08.026, 2012.

Li, W. X., Lundberg, J., Dickin, A. P., Ford, D. C., Schwarcz, H. P., McNutt, R., and Williams, D.: High-precision massspectrometric uranium-series dating of cave deposits and im- plications for palaeoclimate studies, Nature, 339, 534-536, https://doi.org/10.1038/339534a0, 1989.

Lundberg, J. and Ford, D. C.: Late Pleistocene sea level change in the Bahamas from mass spectrometric U-series dating of submerged speleothem, Quaternary Sci. Rev., 13, 1-14, https://doi.org/10.1016/0277-3791(94)90121-x, 1994.

McNeill, D. F.: Accumulation rates from well-dated late Neogene carbonate platforms and margins, Sediment. Geol., 175, 73-87, https://doi.org/10.1016/j.sedgeo.2004.12.032, 2005.

Miklavič, B., Yokoyama, Y., Urata, K., Miyairi, Y., and Kan, H.: Holocene relative sea level history from phreatic overgrowths on speleothems (POS) on Minami Daito Island, Northern Philippine Sea, Quatern. Int., 471, 359-368, https://doi.org/10.1016/j.quaint.2017.09.032, 2018.

Mitrovica, J. X. and Milne, G. A.: On post-glacial sea level: I. General theory, Geophys. J. Int., 154, 253-267, https://doi.org/10.1046/j.1365-246X.2003.01942.x, 2003.

Moseley, G. E., Smart, P. L., Richards, D. A., and Hoffmann, D. L.: Speleothem constraints on marine isotope stage (MIS) 5 relative sea levels, Yucatan Peninsula, Mexico, J. Quat. Sci., 28, 293300, https://doi.org/10.1002/jqs.2613, 2013.

Muhs, D. R., Simmons, K. R., Schumann, R. R., Schweig, E. S., and Rowe, M. P.: Testing glacial isostatic adjustment models of last-interglacial sea level history in the Bahamas and Bermuda, Quat. Sci. Rev., 233, 106212, https://doi.org/10.1016/j.quascirev.2020.106212, 2020.

Mylroie, J., Lace, M., Albury, N., and Mylroie, J.: Flank margin caves and the position of Mid- to Late Pleistocene sea level in the Bahamas, J. Coastal Res., 36, 249-260, https://doi.org/10.2112/JCOASTRES-D-18-00174.1, 2020.

Onac, B. P., Gineìs, A., Gineìs, J., Fornós, J. J., and Dorale, J. A.: Late Quaternary Sea-level History: a Speleothem Perspective, in: Mallorca: a Mediterranean benchmark for Quaternary studies, Monografies de la Societat d'Història Natural de les Balears, 147-162, 2012.

Pedoja, K., Husson, L., Johnson, M. E., Melnick, D., Witt, C., Pochat, S., Nexer, M., Delcaillau, B., Pinegina, T., Poprawski, Y., Authemayou, C., Elliot, M., Regard, V., and Garestier, F.: Coastal staircase sequences reflecting sea-level oscillations and tectonic uplift during the Quaternary and Neogene, Earth-Sci. Rev., 132, 13-38, https://doi.org/10.1016/j.earscirev.2014.01.007, 2014.

Polyak, V. J., Onac, B. P., Fornós, J. J., Hay, C., Asmerom, Y., Dorale, J. A., Ginés, J., Tuccimei, P., and Ginés, A.: A highly resolved record of relative sea level in the western Mediterranean Sea during the last interglacial period, Nat. Geosci., 11, 860-864, https://doi.org/10.1038/s41561-018-0222-5, 2018.

Pomar, L., Ginés, A., and Fontarnau, R.: Las cristalizaciones freáticas, Endins, 3-25, 1976.

Richards, D. A.: Pleistocene sea levels and palaeoclimate of the Bahamas based on ${ }^{230} \mathrm{Th}$ ages of speleothems, University of Bristol, Bristol, UK, 1995.

Richards, D. A. and Dorale, J. A.: Uranium-series chronology and environmental applications of speleothems, Rev. Mineral Geochem., 52, 407-460, https://doi.org/10.2113/0520407, 2003.

Richards, D. A., Smart, P. L., and Edwards, R. L.: Maximum sea levels for the last glacial period from U-series ages of submerged speleothems, Nature, 367, 357-360, https://doi.org/10.1038/367357a0, 1994. 
Richards, D. A., Smart, P. L., Nita, D. C., Moseley, G. E., Hoffmann, D. L., and Edwards, R. L.: Constraining sea level change at the end of marine isotope stage 5 using high-resolution subsamples of a Bahamas flowstone, in: NSF Workshop Sea-level changes into the MIS 5: from observations to prediction, Palma de Mallorca, Mallorca, 10-14 April 2012, 46-47, 2012.

Rovere, A., Raymo, M. E., Vacchi, M., Lorscheid, T., Stocchi, P., Gómez-Pujol, L., Harris, D. L., Casella, E., O'Leary, M. J., and Hearty, P. J.: The analysis of Last Interglacial (MIS 5e) relative sea-level indicators: Reconstructing sealevel in a warmer world, Earth-Sci. Rev., 159, 404-427, https://doi.org/10.1016/j.earscirev.2016.06.006, 2016a.

Rovere, A., Stocchi, P., and Vacchi, M.: Eustatic and relative sea level changes, Current Climate Change Reports, 2, 221-231, https://doi.org/10.1007/s40641-016-0045-7, 2016b.

Rovere, A., Ryan, D., Murray-Wallace, C., Simms, A., Vacchi, M., Dutton, A., Lorscheid, T., Chutcharavan, P., Brill, D., Bartz, M., Jankowski, N., Mueller, D., Cohen, K., and Gowan, E.: Descriptions of database fields for the World Atlas of Last Interglacial Shorelines (WALIS), Zenodo, https://doi.org/10.5281/zenodo.3961544, 2020.

Shennan, I.: Framing research question, in: Handbook of sea-level research, edn. 1, edited by: Shennan, I., Long, A. J., and Horton, B. P., John Wiley \& Sons, 2015.

Skrivanek, A., Li, J., and Dutton, A.: Relative sea-level change during the Last Interglacial as recorded in Bahamian fossil reefs, Quaternary Sci. Rev., 200, 160-177, https://doi.org/10.1016/j.quascirev.2018.09.033, 2018.

Smart, P. L., Moseley, G. E., Richards, D. A., and Whitaker, F. F.: Past high sea-stands and platform stability: evidence from Conch Bar Cave, Middle Caicos, in: Developing models and analogs for isolated carbonate platforms - Holocene and Pleistocene carbonates of Caicos Platform, British West Indies, edited by: Morgan, W. A. and Harris, P. M., SEPM Society for Sedimentary Geology, 203-210. 2008.

Smart, P. L., Richards, D. A., and Edwards, R. L.: Uranium-series ages of speleothems from South Andros, Bahamas: implications for Quaternary sea-level history and palaeoclimate, Cave and Karst Science, 25, 67-74, 1998.

Spalding, R. F. and Mathews, T. D.: Stalagmites from caves in the Bahamas: Indicators of low sea level stand, Quat. Res., 2, 470472, https://doi.org/10.1016/0033-5894(72)90085-3, 1972.

Spötl, C. and Mattey, D.: Scientific drilling of speleothems - a technical note, Int. J. Speleol., 41, 29-34, 2012.

Surić, M. and Juračić, M.: Late Pleistocene - Holocene environmental changes - records from submerged speleothems along the Eastern Adriatic coast (Croatia), Geol. Croat., 63, 155-169, 2010 .
Surić, M., Richards, D. A., Hoffmann, D. L., Tibljaš, D., and Juračić, M.: Sea-level change during MIS 5a based on submerged speleothems from the eastern Adriatic Sea (Croatia), Mar. Geol., 262, 62-67, https://doi.org/10.1016/j.margeo.2009.03.005, 2009.

Thompson, W. G., Allen Curran, H., Wilson, M. A., and White, B.: Sea-level oscillations during the last interglacial highstand recorded by Bahamas corals, Nat. Geosci., 4, 684-687, https://doi.org/10.1038/ngeo1253, 2011.

Tuccimei, P., Fornós, J. J., Ginés, A., Ginés, J., Gràcia, F., and Mucedda, M.: Sea level change at Capo Caccia (NW Sardinia) and Mallorca (Balearic Islands) during oxygen isotope substage $5 \mathrm{e}$, based on $\mathrm{Th} / \mathrm{U}$ datings of phreatic overgrowths on speleothems, in: Geomorfologia Litoral i Quaternari, Homenatge a Joan Cuerda Barcelo, Monografies de la Societat d'Historia Natural de les Balears, edited by: Pons, G. X. and Vicens, D., 121-136, 2007.

Tuccimei, P., Onac, B. P., Dorale, J. A., Ginés, J., Fornós, J. J., Ginés, A., Spada, G., Ruggieri, G., and Mucedda, M.: Decoding last interglacial sea-level variations in the western Mediterranean using speleothem encrustations from coastal caves in Mallorca and Sardinia: A field data - model comparison, Quatern. Int., 262, 56-64, https://doi.org/10.1016/j.quaint.2011.10.032, 2012.

Turney, C. S. M. and Jones, R. T.: Does the Agulhas Current amplify global temperatures during super-interglacials?, J. Quaternary Sci., 25, 839-843, https://doi.org/10.1002/jqs.1423, 2010.

Urushibara-Yoshino, K.: Karst terrain of raised coral islands, Minamidaito and Kikai in the Nansei Islands of Japan, Z. Geomorphol. Supp., 131, 17-31, 2003.

Van Hengstum, P. J., Richards, D. A., Onac, B. P., and Dorale, J. A.: Coastal caves and sinkholes, in: Handbook of sea-level research, edn. 1, edited by: Shennan, I., Long, A. J., and Horton, B. P., John Wiley \& Sons, 2015.

Vesica, P. L., Tuccimei, P., Turi, B., Fornós, J. J., Ginés, A., and Ginés, J.: Late Pleistocene Paleoclimates and sea-level change in the Mediterranean as inferred from stable isotope and U-series studies of overgrowths on speleothems, Mallorca, Spain, Quaternary Sci. Rev., 19, 865-879, https://doi.org/10.1016/S02773791(99)00026-8, 2000.

Wainer, K. A. I., Rowe, M. P., Thomas, A. L., Mason, A. J., Williams, B., Tamisiea, M. E., Williams, F. H., Düsterhus, A., and Henderson, G. M.: Speleothem evidence for MIS 5c and 5a sea level above modern level at Bermuda, Earth Planet. Sc. Lett., 457, 325-334, https://doi.org/10.1016/j.eps1.2016.10.005, 2017. 